\title{
Ccr4 is a novel shuttle factor required for ubiquitin-dependent proteolysis by the $26 \mathrm{~S}$ proteasome
}

\author{
Ganapathi Kandasamy ${ }^{\Psi}$, Ashis Kumar Pradhan ${ }^{\Psi}$, R Palanimurugan* \\ CSIR-Center for Cellular and Molecular Biology, Uppal Road, Habsiguda, Hyderabad, \\ India, 500007
}

$\Psi$ Equally contributing first authors

*Corresponding author, email: murugan@ccmb.res.in

\begin{abstract}
Degradation of short-lived and abnormal proteins are essential for normal cellular homeostasis. In eukaryotes, such unstable cellular proteins are selectively degraded by the ubiquitin proteasome system (UPS). Furthermore, abnormalities in protein degradation by the UPS have been linked to several human diseases. Ccr4 protein is a known component of the Ccr4-Not complex, which has established roles in transcription, mRNA de-adenylation and RNA degradation etc. Excitingly in this study, we show that Ccr4 protein has a novel function as a shuttle factor that promotes ubiquitin-dependent degradation of short-lived proteins by the $26 \mathrm{~S}$ proteasome. Using a substrate of the well-studied ubiquitin fusion degradation (UFD) pathway, we found that its UPS-mediated degradation was severely impaired upon deletion of CCR4 in Saccharomyces cerevisiae. Additionally, we show that Ccr4 binds to cellular ubiquitin conjugates and the proteasome. In contrast to Ccr4, most other subunits of the Ccr4-Not complex proteins are dispensable for UFD substrate degradation. From our findings we conclude that Ccr4 functions in the UPS as a shuttle factor targeting ubiquitylated substrates for proteasomal degradation.
\end{abstract}

Keywords: Ubiquitin fusion degradation (UFD), N-end rule pathway, Ccr4-Not complex, Proteasome, Ubiquitin shuttle factor 


\section{Introduction}

Normal cellular homeostasis requires the cells to regulate and/or degrade functional as well as non-functional proteins by proteolysis. In eukaryotes, the most important proteolytic system that is essential for selectively degrading such proteins is the ubiquitin proteasome system. Prior to degradation, the substrate proteins are marked with ubiquitin by a set of enzymes (E1, E2 and E3); then the ubiquitin-modified proteins are degraded by the $26 \mathrm{~S}$ proteasome (Budenholzer et al., 2017; Dikic, 2017; Marques et al., 2009; Varshavsky, 2017). There are many diseases and abnormalities that are linked to defective protein degradation including parkinson's, alzheimer diseases, cancer and muscular dystrophy etc. (Reinstein and Ciechanover, 2006; Rousseau and Bertolotti, 2018; Vinciguerra et al., 2010). The significance of UPS has been eminent after identification of many substrates of the proteasome including major regulatory factors such as cell cycle proteins (Cyclins) and signaling proteins (Rose and Mayor, 2018). Groundbreaking studies have lead to the characterization of specific protein degradation pathways in eukaryotes, such as the $\mathrm{N}$-end rule (Bachmair et al., 1986; Dohmen et al., 1991; Ghislain et al., 1996; Madura et al., 1993) and ubiquitin fusion degradation pathways (Johnson et al., 1995), both of which depend on dedicated enzymes (E1, E2, E3 and DUBs) involved in ubiquitylation and de-ubiquitylation. Further studies on the same line resulted in the identification of proteins relating to the function of the proteasome (Ramos et al., 1998; Varshavsky, 2011). Several Ufd proteins, for example, Ufd1 to Ufd5 are required for the ubiquitin-dependent degradation of linear ubiquitin fusion proteins in the UFD pathway in eukaryotes. Specifically, Ufd4 is an ubiquitin ligase (E3) (Johnson et al., 1995), together with the ubiquitin-conjugating enzymes Ubc4 and Ubc5 (E2s) attaches ubiquitin to the UFD substrates. In the next step, Cdc48 Ufd1/Npl4/Ufd2 complex binds to mono and/or di-ubiquitin modified UFD substrates, then the U-box containing protein Ufd2 elongates ubiquitin chain thereby optimizing the chain length and topology for efficient recognition and degradation by the proteasome (Richly et al., 2005). In an interesting study, Ubr1 (E3 for N-end rule pathway substrates) was found to form a complex with Ufd4 to ubiquitylate the DNA repair protein Mgt1 in yeast (Hwang et al., 2010). 
Ufd3 is a $80 \mathrm{KDa}$ protein required for the degradation of UFD as well as the Nend rule substrates by the proteasome (Hwang et al., 2010). Although the molecular function of Ufd3 is still largely unknown, it is clear that it binds to Cdc48 and required for ubiquitin recycling as the free ubiquitin levels were found to be low upon UFD3 deletion (Johnson et al., 1995). Ufd5, also known as Rpn4, is a transcription factor that is involved in regulating expression of UPS genes and controls proteasome levels. Therefore, a deletion of UFD5/RPN4 results in stabilization of various substrates that are destined to be degraded by the proteasome (London et al., 2004; Xie and Varshavsky, 2001).

Aside from ubiquitin ligases (E3s) that functions as monomers or dimers, there are several E3s found to be multimeric proteins, such as anaphasepromoting complex (APC or cyclosome), SCF or Ccr4-Not complex (Nakayama and Nakayama, 2006; Page and Hieter, 1999; Peters, 1998; Vodermaier, 2004). The Ccr4-Not complex is a highly conserved protein complex present in all eukaryotes (Collart and Panasenko, 2017). Although, the composition of Ccr4Not complexes vary slightly in different organisms, in yeast the Ccr4-Not complex is composed of at least nine subunits namely Ccr4, Caf1, Caf40, Caf130, Not1, Not2, Not3, Not4 and Not5 (Chen et al., 2001; Collart, 2003). The Ccr4-Not complex has multiple functions ranging from mRNA de-adenylation, RNA degradation, transcriptional regulation to translational control etc. (Inada and Makino, 2014)(Collart and Panasenko, 2017). Additionally, the Ccr4-Not complex is known to interact with several protein complexes including proteasome (Laribee et al., 2007) (Figure 7), ribosome and molecular chaperones (Preissler et al., 2015; Villanyi et al., 2014). Interestingly, the shared nuclease catalytic center in Ccr4-Not complex is composed of Ccr4, Caf1 and Not1 subunits (Basquin et al., 2012; Petit et al., 2012). The Not4 subunit contains a canonical RING motif, which is found in a class of ubiquitin ligases, and required for degradation of several proteasome substrates (Cooper et al., 2012; Gulshan et al., 2012; Mersman et al., 2009; Panasenko et al., 2006; Panasenko and Collart, 2012; Simonetti et al., 2017). However, the direct involvement of Not4 in ubiquitin modification of proteasome substrates has not been demonstrated so far. A recent study showed that Not4 can modify the Rpt5 subunit in the $19 \mathrm{~S}$ 
regulatory particle (RP) of the $26 \mathrm{~S}$ proteasome by monoubiquitylation in vitro (Fu et al., 2018). Ubiquitin modified Rpt5 is not subjected to protein degradation. Furthermore, in higher eukaryotes Not4 is not a part of the Ccr4-Not complex and there are a few additional subunits that are specifically found only in Drosophila and human Ccr4-Not complexes (Collart and Panasenko, 2017; Temme et al., 2010) suggesting that the precise molecular function of Not4 in protein degradation remains to be explored. Further investigations found that Not2, Not3 and Not5 subunits were required for 5' de-capping of mRNA prior to its degradation (Alhusaini and Coller, 2016). Although the exact molecular functions of Caf40 and Caf130 are still unknown, these polypeptides are implicated in stabilizing the interactions in the Ccr4-Not complex, thereby contributing to its de-adenylation and ubiquitylation functions (Keskeny et al., 2019). Importantly, the Ccr4-Not complex also has been implicated in several diseases such as obesity, diabetes and liver steatosis (Morita et al., 2011). Additionally, the Ccr4-Not complex also has a role in energy metabolism (Morita et al., 2011). In an intriguing earlier observation, the deletion of CCR4 and CAF1 showed similar phenotypes when compared to the other NOT gene deletions found in Ccr4-Not complex (Halter et al., 2014). On the other hand, NOT gene deletions showed similar phenotypes when compared among the NOT genes suggesting that the Not proteins might also form a sub complex apart from being part of Ccr4-Not complex. Similarly, Ccr4 and Caf1 might also constitute a distinct complex that is independent of the Ccr4-Not complex (Winkler and Balacco, 2013). Ccr4 has earlier been shown to bind to the regulatory particle (RP) of the $26 \mathrm{~S}$ proteasome indicting that Ccr4 might have role in protein degradation (Laribee et al., 2007) (Figure 7). Such role, however, has not been demonstrated until now. In this study, we investigated the role of the Ccr4-Not complex in degradation of ubiquitin-dependent as well as ubiquitin-independent substrates by the $26 \mathrm{~S}$ proteasome. Our findings let us to conclude that Ccr4 is required for degradation of ubiquitin-dependent substrates. Upon deletion of CCR4, the UFD substrate degradation is severely impaired, and the CCR4 mutant accumulates UFD substrate in the ubiquitin-modified form. From our results, we hypothesize that Ccr4 might function as a shuttle and/or targeting factor for ubiquitin-modified proteasome substrates. 


\section{Materials and Methods}

Yeast media: Complete yeast peptone dextrose (YPD) and synthetic dextrose (SD) minimal media having $2 \%$ dextrose (glucose or galactose) with specific dropouts were prepared as described earlier (Ramos et al., 1998) (Palanimurugan et al., 2004) and used in this entire study.

Strains and plasmids: BY4741 wild type yeast strain and its derivatives were used in this study are listed in the strain table attached in the supplemental information. The TRP1 gene was deleted in BY4741 and $c c r 4 \Delta$ strains using a technique described earlier (Alani et al., 1987). In order to do that, pNKY1009 plasmid was digested with BglII and EcoRI to release a deletion cassette. The released fragment was used to transform respective yeast strains and $\mathrm{Ura}^{+}$and Trp- colonies were selected on appropriate media. In the following step, the URA3 gene was cured out by streaking out the selected colonies on SD medium containing (1g/l) 5-Fluoroorotic acid hydrate (Sigma) plates as described previously (Boeke et al., 1984). The genotypes of the resulting PYGA12 and PYGA14 strains are listed in the supplementary strain table $1 \mathrm{~A}$.

YAP16 strain was generated integrating a KanMX4::P $P_{G A L 1}-\mathrm{PRE} 2$ cassette which was PCR amplified using the PRE2 gene flanking primers (GK449 and GK450) from genomic DNA isolated from YGA140 strain. PCR amplified DNA was used to transform PYGA12, and the transformants were selected on YPGalG418 plate $(300 \mu \mathrm{g} / \mathrm{ml})$. Plasmids pMAF17 ( $\left.P_{C U P 1}-\mathrm{UB}-\mathrm{R}-\mathrm{eKa}-\mathrm{HA}-\mathrm{URA} 3\right), \mathrm{pMAF} 18$

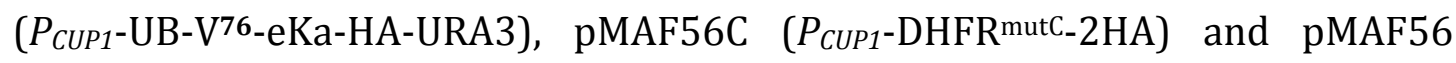
$\left(P_{C U P 1}-D_{H F R}{ }^{W T}-2 H A\right)$ are derived from the CEN/LEU2 vector pRS315 (Sikorski and Hieter, 1989) and pBA2VV is derived from CEN/TRP1 vector pRS314, were kind gifts from R.J. Dohmen. pDG258 (PSPE1-ODS-URA3-2HA) is also derived from yeast CEN/LEU2 vector pPM91 as described (Godderz et al., 2011; Kurian et al., 2011). pAK14 (PCCR4-CCR4- $\left.T_{C C R 4}\right)$ is derived from $C E N / L E U 2$ vector Ycplac111(Gietz and Sugino, 1988). This vector was digested with EcoRI and KpnI, then the CCR4 fragment-1 containing promoter and a 5' part of the CCR4 
ORF was generated using primers AP348 and AP349 and digested with EcoRI and HindIII, and a CCR4 fragment-2 containing a 3' part of CCR4 ORF and terminator was generated using primers AP350 and AP351 and digested with HindIII and KpnI then used for ligation. For generating CCr4 deletion constructs CEN/LEU2 vector Ycplac111 was used as a vector backbone. To construct Ccr4 1$187 \Delta, 331-837 \Delta$, and $1-417 \Delta$ the insert 1 carrying the CCR4 promoter region was PCR amplified and double digested with EcoRI and HindIII. Next, the insert 2 either carrying nucleotides corresponding to Ccr4 188-837 (pGAP3), 332-837 (pGAP4) or 418-837 (pGAP5) amino acid was PCR amplified and double digested with Hind III and KpnI and finally ligated to Ycplac111 digested with EcoRI and KpnI restriction enzymes. For construction of Ccr4 418-8374, the insert 1 carrying the CCR4 promoter and nucleotides corresponding to 1-417 amino acids of CCR4 (pAK21) was PCR amplified and double digested with E.coRI and BamHI, and the insert 2 carrying the CCR4 terminator region was PCR amplified and digested with BamHI and KpnI and finally ligated to Ycplac111 digested with E.coRI and KpnI. pAK20 (P $P_{T P 11}-$ CCR4-3XFLAG) is derived from the CEN/URA3 vector pGAP1. The pGAP1 vector was digested with SacI and KpnI and ligated to equally digested $P_{T P I 1}$-CCR4-3XFLAG. The inserts were derived by PCR amplification using the primers listed in the supplementary table 1A. YEp105 (expressing $P_{C U P I}-\mathrm{MYC}-\mathrm{UB}$ ) is a $2 \mu / T R P 1$ plasmid (Ellison and Hochstrasser, 1991). All the primers and plasmid details are listed in the supplementary table $1 \mathrm{~B} \& \mathrm{C}$ respectively.

Yeast growth condition: Yeast strains were grown on YPD or SD agar plates at $25^{\circ} \mathrm{C}$. For growth in YPD or SD liquid media, yeast cultures were incubated at $25^{\circ} \mathrm{C}$ with shaking at $180 \mathrm{rpm}$. For temperature-sensitive mutants, the growth conditions are described for the respective experiments in the results section.

Western blotting analysis for protein detection and quantification: To assay the steady state levels of the substrate proteins, S. cerevisiae transformants were inoculated and grown overnight at $25^{\circ} \mathrm{C}$ in SD medium lacking leucine (SD-Leu) as described earlier. The primary cultures were then diluted in fresh SD-Leu medium $\left(\mathrm{OD}_{600}-0.2\right)$, and the cells corresponding to $5.0 \mathrm{OD}$ ware harvested at 
mid log phase $\left(\mathrm{OD}_{600}\right.$ - 0.8 to 1.0$)$. The cell pellets were washed once with water then mixed with $250 \mu \mathrm{l}$ of ice cold $1.85 \mathrm{~N} \mathrm{NaOH}$. After incubation for 10 min on ice, $250 \mu \mathrm{l}$ of $50 \%$ TCA was added to each sample. Then cells were pelleted by centrifuging at $14,000 \mathrm{rpm}$ for $10 \mathrm{~min}$, the supernatant was discarded, the cells were re-suspended in $100 \mu \mathrm{l}$ of $1 \mathrm{M}$ Tris ( $\mathrm{pH}$ 7.5), and pelleted again as mentioned above. In the next step, the pellet was re-suspended in 1X Laemmli loading buffer (0.0625M Tris-HCl (pH 6.8), 2\% SDS, 1\% $\beta$-mercaptoethanol, 10\% glycerol, $0.002 \%$ bromophenol blue) and lysed by boiling at $85^{\circ} \mathrm{C}$ for $5 \mathrm{~min}$. After a brief centrifugation, the yeast cell extracts corresponding to $0.416 \mathrm{OD}_{600}$ were loaded on to a gel, then SDS-PAGE and western blotting were done to detect the specific proteins as well as to quantify the corresponding bands as described earlier (Palanimurugan et al, 2004, Kurian et al, 2011). Anti-Ha (C29F4 from cell signaling technologies, 1:2000 dilution) was used for detecting ha-tagged proteins. Anti-Tpi1 (Lab source, 1:10000 dilution) and Anti-Pgk1 (Novex, 1:5000 dilution) were used to detect Tpi1 and Pgk1. Proteins were detected using either secondary anti-mouse or anti-rabbit IgG coupled to peroxidase (Millipore, 1:5000 dilution), western bright ECL substrate (Advansta) was used for developing the blots. The signals were captured using a Bio-Rad ChemiDoc ${ }^{\mathrm{TM}} \mathrm{MP}$ Imaging system and quantified using the software Bio-Rad Image Lab 6.0.1.

Cycloheximide chase analysis for assaying protein stability: Protein stability was assayed by cycloheximide chase analysis. Exponentially growing yeast cells were treated with $100 \mathrm{mg} / \mathrm{L}$ cycloheximide; then samples were collected at appropriate time points. Samples were then washed, lysed and analyzed on SDSPAGE followed by immuno-blotting as described above. Signals were quantified and protein degradation rates were calculated as mentioned (Kurian et al., 2011; Palanimurugan et al., 2004).

Immunoprecipitation of Ccr4-Flag: Yeast strain YAP16 (BY4741, KanMX4::P $P_{G A L 1}$-PRE2) was either transformed with empty plasmids (YCplac111 and YEplac112) or its isogenic derivates expressing MYC-UB (YEp105) and CCR4-3XFLAG (pAK20). Transformants were selected on synthetic galactose media plates and primary cultures were grown in galactose medium until unless 
mentioned. For shutdown of expression from $P_{G A L 1}$, primary cultures were diluted into fresh liquid medium containing $2 \%$ glucose and grown at $25^{\circ} \mathrm{C}$ for 12 hrs. For immunoprecipitation, cells corresponding to $40 \mathrm{OD}_{600}$ were harvested and the pellets were frozen at $-65^{\circ} \mathrm{C}$. For lysis, pellets were thawn and re-suspended in $400 \mu \mathrm{l}$ of lysis buffer (50mM HEPES pH7.5, 150mM NaCl, $5 \mathrm{mM}$ $\mathrm{MgCl}_{2}, 40 \mathrm{mM} \mathrm{N}$ - Ethylmaleimide, EDTA-free protease inhibitor cocktail (Roche) and $2 \mathrm{mM}$ PMSF (Sigma); then $300 \mu \mathrm{l}$ of acid washed glass beads (425-600 $\mu \mathrm{M}$ from Sigma) was added to the cell suspension, then tubes were vortexed 3X1 min each with incubation on ice for $2 \mathrm{~min}$ in-between. After clearing cell debris, the lysate was mixed with Triton X-100 (1\% final concentration) and centrifuged at $14,000 \mathrm{rpm}$ for $10 \mathrm{~min}$ at $4^{\circ} \mathrm{C}$. Equal amounts (Protein estimation by Bradford) of soluble fractions were incubated with $40 \mu \mathrm{l}$ of pre-equilibrated anti-FLAG M2 affinity agarose gel (Sigma) in binding buffer (Lysis buffer $+1 \%$ Triton X-100). Binding was done at $4^{\circ} \mathrm{C}$ for $2 \mathrm{hrs}$; then beads were washed $3 \mathrm{X} 5 \mathrm{~min}$ each with binding buffer. Ccr4-3XFLAG protein was specifically eluted using $70 \mu$ l elution buffer (binding buffer plus $35 \mu \mathrm{g}$ of $3 \mathrm{X}$ FLAG peptide from sigma). Eluted materials were boiled and analyzed by SDS-PAGE. Anti-Flag (Sigma, 1:2000 dilution) or anti-Myc (9B11, Cell Signaling Technologies, 1:1000 dilution) was used for protein detection. Immunoprecipitation of Ccr4-3XFLAG was also done under non-native conditions. For this purpose, soluble cell lysates were prepared as described above and SDS (2\%) as well as $\beta$-mercaptoethanol (1\%) were added. The samples were then boiled at $95^{\circ} \mathrm{C}$ for $5 \mathrm{~min}$. Next, the samples were diluted to reduce the SDS and $\beta$-mercaptoethanol to $0.05 \%$ and $0.025 \%$ respectively. Diluted samples were incubated with $60 \mu \mathrm{l}$ of pre equilibrated antiFLAG M2 affinity agarose gel and washed prior to elution as described above. Ccr4-3XFLAG was eluted using $80 \mu \mathrm{l}$ of $3 \mathrm{X}$ Flag peptide ( $40 \mu \mathrm{g}$ in binding buffer).

\section{Co-immunoprecipitation of Ccr4-Flag and Rpt5}

Yeast strain YAP16 carrying either empty vector plasmid YCplac111 or pAK20 plasmid expressing Ccr4-3XFLAG was grown till mid-log phase at $25^{\circ} \mathrm{C}$ in galactose containing medium. Cells corresponding to $100 \mathrm{OD}_{600}$ were harvested and stored at $-65^{\circ} \mathrm{C}$ until further use. Cell pellets were resuspended in $600 \mu \mathrm{l}$ of 
lysis buffer and the soluble extracts were prepared as described in the previous section. The Ccr4-3XFLAG protein was bound to anti-FLAG M2 affinity agarose gel as mentioned earlier in the native co-immunoprecipitation protocol. After extensive washing the bound proteins are eluted and co-purification of Rpt5 with CCr4-FLAG protein was detected by using western blotting.

\section{Results}

\section{Certain proteasome substrates accumulate upon deletion of $C C R 4$}

In Saccharomyces cerevisiae, the Ccr4-Not complex is composed of several subunits including Not and Caf polypeptides (see introduction). Distinct phenotypes were observed for strains with NOT gene deletions compared to one with CAF or CCR4 gene deletions. Not4, in yeast a subunit of the Ccr4-Not complex, is a RING finger ubiquitin ligase, which has been shown to interact with yeast proteasomes. In contrast, Not4 protein is not a stable subunit of the human and Drosophila Ccr4-Not complexes. Interestingly, another study revealed the interactions of remaining Ccr4-Not complex proteins Ccr4, Not1 and Not4 and these proteins were found to interact with 19S regulatory particle of the $26 \mathrm{~S}$ proteasome (Laribee et al., 2007) (Figure 7). The above findings let us to hypothesize that the Ccr4-Not complex or its components might have functions in protein degradation by the UPS apart from its earlier well-characterized roles in RNA metabolism and translational control. We have particularly focused on the Ccr4 subunit of the Ccr4-Not complex in this study. Ccr4 has not been found to have any role in protein turnover despite the above-mentioned observation of its interaction with 19S RP. In order to test our hypothesis, we have expressed several known well-characterized UPS substrates (R-Ura3, Ub-V76-Ura3, DhfrmutC, ODS-Ura3) that are degraded via ubiquitin-dependent and independent mechanisms by the $26 \mathrm{~S}$ proteasome (Figure 1 ) in yeast, and assayed their steady state levels in wild type, ccr $4 \Delta$ and ump $1 \Delta$ strains. The latter is impaired in proteasome function due to the absence of the assembly and maturation factor Ump1 and served as a control (Ramos et al. 1998). As expected, our steady state 
level analysis showed that the ump1s mutant, relative to the wild type, accumulated all tested proteasome substrates, consistent with a general proteasomal defect (Figure 2A). Surprisingly, the UFD pathway substrate Ub-V76. Ura3 as well as the $\mathrm{N}$-end rule pathway substrate R-Ura3 accumulated in the ccr4 $\Delta$ mutant. Importantly, we observed that ectopic expression of wild type CCR4 or of CCR4-FLAG restored the Ub-V76-Ura3 substrate degradation in ccr4 $\Delta$ strain (Figure 2B), confirming that the increased levels were indeed due to the absence of Ccr4. In contrast to these two proteolytic substrates, the levels of two other test proteins were unaffected by the deletion of CCR4. Specifically, levels of Dhfrmutc, a folding-deficient mutant version of mouse dihydrofolate reductase is known to be degraded in chaperone-mediated and ubiquitin-dependent manner, were not increased in $c c r 4 \Delta$ mutant. Moreover, also the levels of ODS-Ura3, a modified version of the Ura3 protein carrying the N-terminal degradation signal of ornithine decarboxylase (ODC degradation signal/ODS), which is known to be degraded in a ubiquitin-independent manner (Gödderz et al. 2011), were also similar in wild type and $c c r 4 \Delta$ strain. We also tested if $c c r 4 \Delta$ would alter the transcription from $\mathrm{P}_{\mathrm{CUP} 1}$ by using stable Dhfr as a control. Our result showered that expression from $\mathrm{P}_{\text {CUP1 }}$ was not altered in $c c r 4 \Delta$ strain (Supplemental Figure 2). Together, these findings indicated that Ccr4 is required for efficient degradation of some but not all proteasomal substrates.

Considering the accumulation of certain proteasomal substrates in the ccr4 $\Delta$ strain, we wanted to address the involvement of the remaining Ccr4-Not complex subunits in the substrate degradation. To this end, we have assayed the

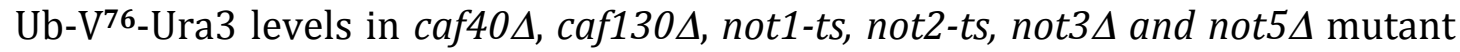
strains. Our results show that Ub-V76-Ura3 levels did not change significantly compared to wild type levels in any of these mutants (Figure 3A). In addition, we monitored the growth of wild type, $c c r 4 \Delta$, ump1 $1 \Delta$, and $u f d 4 \Delta$ strains expressing Ub-V76-Ura3 protein in medium lacking uracil. All these strains carry a mutation in the chromosomal URA3 locus and require either sufficient amount of plasmidencoded Ura3 protein or uracil in the media for normal growth. Only upon an impaired degradation of the above-mentioned Ura3-based test proteins, the strains should be able to grow on medium without uracil. Our assay revealed 
that expression of Ub-V $\mathbf{7}^{6}$-Ura3 promoted growth of ccr4 4 , ump1 $\Delta$ and $u f d 4 \Delta$ cells (Ufd4 is the E3 for UFD substrates)(Johnson et al., 1995) (Figure 3B) suggesting that Ub-V $\mathrm{V}^{\mathbf{7 6}}$-Ura3 accumulates upon CCR4 deletion consistent with the observed increased steady state levels shown in figure 2.

\section{UFD substrate turnover is impaired in the CCR4 mutant}

The observed increased steady state levels of Ub-V76-Ura3 in ccr4 $\Delta$ mutant could be due to the following reasons. Firstly, the rate of synthesis of Ub-V76-Ura3 could have been altered at the transcription and/or translation steps resulting in increased protein levels. Alternatively, the stability of Ub-V76-Ura3 could have increased due to CCR4 deletion. In order to identify the cause, we performed cycloheximide chase analyses to measure the Ub-V76-Ura3 turnover rates in wild type, ccr4 $\Delta$ and ump1s strains. Surprisingly, we found that Ub-V76-Ura3 degradation was blocked upon deletion of CCR4, while the protein degradation was normal in the wild type strain (Figure 4A, B). The control ump1A strain showed even stronger stabilization of Ub-V76-Ura3. These observations suggest that Ccr4 is a novel factor essential for degradation of Ub-V76-Ura3. Similarly, we have performed cycloheximide chase analysis for ODS-Ura3 and Dhfrmutc. The results show that ODS-Ura3 as well as DhfrmutC were degraded normally in ccr4 $\Delta$ strain (Supplemental Figure 1) suggesting that among the tested substrates Ccr4 is not required specifically for the degradation of ODS-Ura3 as well as DhfrmutC.

\section{Ccr4 binds to cellular ubiquitin conjugates}

Our finding that Ccr4 is required for efficient Ub-V76-Ura3 turnover raises an interesting question. How does Ccr4 promote UFD substrate degradation? To answer this question, we have considered several possible steps in UFD substrate degradation, in which Ccr4 might play a vital role. Broadly, all these steps could be classified in to two parts. A first part is substrate recognition and ubiquitylation and second part is the post-ubiquitylation substrate targeting and degradation. For Ub-V76-Ura3 the following enzymes are involved in ubiquitylation namely Uba1 (E1), Ubc4 and Ubc5 (E2s), Ufd4 (E3) and Cdc48 Np14Ufd1-Ufd2 (processivity factor) for ubiquitin chain elongation. For targeting 
ubiquitin-modified substrates, there are several shuttle factors (such as UBAUBL domain containing proteins Rad23, Dsk2 and Ddi1) that have been identified so far. Shuttle factors on the one hand binds to the ubiquitin chain of the modified substrates via their UBA domains, and on the other hand bind to the proteasome via their UBL domains thereby promoting substrate recognition and subsequent degradation by the $26 \mathrm{~S}$ proteasome. In order to address the above possibilities, we analyzed the ubiquitylation status of Ub-V76-Ura3 in wild type, ccr4 $\Delta$ and ump1s strains. Remarkably, our experiment showed that higher molecular weight ubiquitin-modified forms of Ub-V76-Ura3 accumulated upon deletion of $c c r 4$ similar to what was observed when ump1 was deleted (Figure $5 \mathrm{~A}$ ) suggesting that Ccr4 is required for Ub-V76-Ura3 degradation at the post ubiquitylation step. Based on our result, we hypothesized that Ccr4 could be a novel shuttle factor for ubiquitin-modified substrates similar to those described above. To support our hypothesis,

we tested whether Ccr4 interacts with $26 \mathrm{~S}$ proteasome, indeed our coimmunoprecipitation experiments showed that the $19 \mathrm{~S}$ regulatory particle subunit Rpt5 co-purified with Ccr4 protein (Figure 7), as reported earlier (Laribee et al., 2007). Next, we investigated if Ccr4 could also bind to cellular ubiquitin conjugates by co-immunoprecipitation assay. Excitingly, our results showed that ubiquitin conjugates co-immunoprecipitated along with Ccr4 under native conditions (Figure 5B). Upon denaturation of cellular ubiquitin conjugates, Ccr4 was unable to bind to ubiquitin conjugates (Figure 6). In conclusion, our results identified that the shuttling of ubiquitin-modified proteins to the $26 \mathrm{~S}$ proteasome as a novel molecular function of Ccr4.

\section{LRR and Nuclease domains of Ccr4 are indispensable to target UFD substrate for proteolysis}

Ccr4 is an 837 amino acid residue long protein, it contains three major domains (Basquin et al., 2012). The residues 1 to 332 is rich in $Q / N$ amino acids and it is known to form an unstructured region. Next, 333 till 470 region has five leucine rich repeats and constitutes the LRR domain of Ccr4 protein. From residues 471 to 837 is the c-terminal nuclease domain and executes mRNA deadenylation activity (Basquin et al., 2012). In order to find what region of Ccr4 protein 
contributes to ubiquitin shuttle activity, we generated several Ccr4 deletion constructs (Figure $8 \mathrm{~A}$ ) and studied their effect on UFD substrate degradation. Our results revealed that the constructs expressing both the LRR and nuclease domain (188-837 and 332-837) complements the defective protein degradation phenotype of ccr4 mutant (Figure $8 \mathrm{~B} \& \mathrm{C}$ ). Intriguingly, the constructs expressing either the entire $\mathrm{N}$-terminal/C-terminal region along with part of LRR (1-417 and 418-837 respectively) showed severe impairment in targeting UFD substrate for proteolysis (Figure $8 \mathrm{~B} \& \mathrm{C}$ ). The same observation was further confirmed by growth assay analysis using pBA2VV plasmid producing Ub-V76. Ura3 protein (Figure 8D). Altogether, these findings implicated that both LRR and nuclease domains of Ccr4 is essential for its function to target ubiquitinmodified protein for degradation.

\section{Discussion}

Degradation of unstable proteins in eukaryotes are mainly carried out by the ubiquitin proteasome system and autophagy, which together result in recycling of amino acids and regulation of cellular homeostasis (Budenholzer et al., 2017; Dikic, 2017; Marques et al., 2009; Varshavsky, 2017). In this context, our study revealed that the Ccr4 protein is a novel shuttle factor in the UPS-mediated protein degradation. Ccr4 is an exonuclease known to be an active enzyme in the Ccr4-Not complex and has also been shown to physically interact with proteasome, the ribosome and the ribosome-bound chaperone NAC (nascent peptide associated complex) (Laribee et al., 2007)(Preissler et al., 2015; Villanyi et al., 2014). The biological significance of Ccr4 interaction with these protein complexes however is not established. In a recent study, deletion of CCR4 was shown to result in higher amounts of ubiquitin-modified nascent proteins that are bound to yeast ribosomes (Duttler et al., 2013). Such an increase could be due to several reasons. Firstly, the degradation of ubiquitin-modified nascent proteins could be impaired upon CCR4 deletion or the rate of ubiquitin deconjugation might be reduced. Further, there could have been increased rate of ubiquitin conjugation to nascent proteins associated with ribosomes in the absence of Ccr4 might be the cause of the observed increased levels of so 
modified polypeptides. However, there were no further studies to define the molecular function of Ccr4 among the above mentioned points (Duttler et al., 2013). In the present work we have used several well-characterized substrates of the proteasome that are degraded with ubiquitylation (R-Ura3, Ub-V76-Ura3, Dhfrmutc) or without ubiquitylation (ODS-Ura3). Our results showed that the UFD pathway substrate $\mathrm{Ub}-\mathrm{V}^{\mathbf{7 6}}$-Ura3 and the N-end rule pathway substrate R-Ura3 specifically accumulated in CCR4 deletion strain, while the remaining tested substrates levels were similar to those in wild type (Figure 2). These observations led us to postulate that Ccr4 might be involved in UFD pathway and the same hypothesis was validated by cycloheximide experiments showing that the UFD protein stability was altered in CCR4 mutant strain (Figure 4). While the remaining substrates listed above were degraded normally in CCR4 mutant strain (Supplemental Figure 1), the UFD pathway substrate was stabilized upon the deletion of CCR4. From these results we conclude that the Ccr4 protein is a novel component of the UFD pathway and it is essential for Ub-V76-Ura3 degradation by the $26 \mathrm{~S}$ proteasome. Interestingly, the other Ccr4-Not complex subunit deletion strains did not show any significant variations in Ub-V76-Ura3 levels (Figure 3A) suggesting that either Ccr4 works alone or in a subcomplex with other proteins to mediate UFD substrate degradation. This conclusion was re-validated with growth assays reporting on the intracellular levels of Ura3based reporter proteins (Figure 3B). After discovering that the Ccr4 is required for UFD substrate degradation we wanted to understand at which step in the UFD pathway that Ccr4 promotes Ub-V76-Ura3 substrate degradation. On the one hand Ccr4 could affect the ubiquitylation of UFD substrate, on the other hand Ccr4 could affect the substrate targeting to the proteasome. In addition, Ccr4 could also affect proteasome activity. The observation that the degradation of a folding deficient quality control substrate mouse DhfrmutC is normal in CCR4 deletion strain suggested that the substrate ubiquitylation is not affected in the absence of Ccr4. Additionally, the normal degradation of ODS-Ura3 by the proteasome is also suggesting that Ccr4 does not alter proteasome activity. Therefore the most likely step in which the Ccr4 could play a role appears to be the targeting of ubiquitin modified substrate to the proteasome. Our steady state blot analysis revealed that Ub-V76-Ura3 accumulates high molecular weight 
ubiquitin conjugates in the ccr4 $\Delta$ mutant cells (Figure 5A). Therefore, we conclude that Ccr4 has a novel molecular function as a targeting factor for ubiquitin-modified proteins to the proteasome. As listed in the introduction there are several proteins known to be involved in targeting ubiquitin-modified substrates to the proteasome. Rpn1, Rpn10 and Rpn13 subunits of the 19S caps of the proteasome function as receptors for ubiquitin-modified proteins (Berko et al., 2014; Hofmann and Falquet, 2001; Husnjak et al., 2008; Mayor et al., 2005; Paraskevopoulos et al., 2014; Rosenzweig et al., 2012; Rubin et al., 1997; Saeki, 2017; Shi et al., 2016). In addition Rad23, Dsk2 and Ddi1 shuttle ubiquitinmodified proteins to the proteasome. A hallmark feature of such protein is that they carry a UBA domain that binds to ubiquitin chains on the substrates, and a UBL domain that binds to the proteasome (Chen and Madura, 2002; Kang et al., 2006). These domains architecture allows the shuttle factors to bridge the substrate and the proteasome efficiently. Till now such an ubiquitin binding domain has not been identified in Ccr4. Interestingly, we showed that the Ccr4 protein binds to $19 \mathrm{~S}$ regulatory particle of the $26 \mathrm{~S}$ proteasome (Figure 7) and (Laribee et al., 2007). We therefore asked if Ccr4 would bind to intracellular ubiquitin conjugates. Intriguingly, our IP experiment showed that Ccr4 indeed binds to cellular ubiquitin conjugates (Figure 5B) under native conditions. Upon de-naturation of ubiquitin conjugates, Ccr4 was unable to bind ubiquitin suggesting that Ccr4 requires native conformation of ubiquitin chains for its binding (Figure 6). Furthermore, the same result also excluded the possibility that Ccr4 itself being ubiquitin modified in vivo. Our next analysis revealed that LRR and nuclease domain of Ccr4 protein is essential for it ubiquitin shuttle function (Figure 8) and the exact residues and the regions of the LRR and nuclease domain of Ccr4 responsible for proteasome as well as ubiquitin chain binding remains to be explored and might be present within the LRR and C terminal part of Ccr4 protein.

Our findings indicate that there are still unknown ubiquitin shuttle factors involved in targeting ubiquitin-modified substrates to the proteasome. The same conclusion was derived from a previous study in which yeast cells lacking multiple known shuttle factor shown to be viable (Husnjak et al., 2008). Our 
finding revels such a novel shuttle factor that has different structural characteristics than the known UBA-UBL domain containing proteins (Kang et al., 2006). Interestingly, Ccr4 protein is a highly conserved protein from lower to higher eukaryotes. Based on its structural and functional conservation we postulate that Ccr4 is involved in shuttling ubiquitin conjugates to the proteasome also in mammals. However such interesting hypothesis needs experimental validation and that is beyond the scope of this study.

Based on our understanding of the role of Ccr4 in protein degradation we have developed a model as shown in Figure 9. There is an intriguing list of shuttle factors for targeting of ubiquitin-modified substrates that are described so far. Interestingly, there is an additional layer of substrate selectivity at the substrate-targeting step to the proteasome. Almost all the shuttle factors have preference to bind a particular ubiquitin chain type having a suitable conformation for efficient recognition by the UBA domain or other ubiquitin receptors at the proteasome (Kang et al., 2006). Interestingly, Ccr4 may have preference to certain ubiquitin chain types for targeting. Therefore, it might have role beyond the UFD pathway to target other substrates of the proteasome for degradation. Based upon our findings such interesting possibilities can be explored for further understanding of Ccr4 functions in the UPS. Importantly, many diseases are associated and/or are caused by defects in the protein degradation our enhanced understanding of targeting by Ccr4 with in the UPS may help in finding a therapeutic approaches for such diseases in the future.

\section{Acknowledgment}

This work was supported by funding from DBT-Ramalingaswami fellowship contingency grant as well as extra mural grant from SERB-DST to PMR. We thank Jürgen Dohmen, Marcel Fröhlich and Kerstin Nürrenberg (Institute for Genetics, University of Cologne, Germany), Thomas Langer (Max-Planck Institute for Biology of Ageing, Cologne, Germany), Ana-Mafalda Escobar-Henriques Dias and Ramona Schuster (Institute for Genetics, University of Cologne, Germany), Claes Andréasson (The Wenner-Gren Institute, Stockholm University, Sweden), 
Krishnaveni Mishra (University of Hyderabad, India) for strains as well as plasmids. We also thank Sanjay Suman (CSIR-Center for Cellular and Molecular Biology, Hyderabad, India) for help during this work. We thank Revathi Muthuvel for generating the polyclonal anti-Tpi1 antibody used in this study and Aswani Kumar for his help in preparing the illustrations.

\section{Reference}

Alani, E., Cao, L. and Kleckner, N. (1987). A method for gene disruption that allows repeated use of URA3 selection in the construction of multiply disrupted yeast strains. Genetics 116, 541-5.

Alhusaini, N. and Coller, J. (2016). The deadenylase components Not2p, Not3p, and Not5p promote mRNA decapping. Rna 22, 709-21.

Bachmair, A., Finley, D. and Varshavsky, A. (1986). In vivo half-life of a protein is a function of its amino-terminal residue. Science 234, 179-86.

Basquin, J., Roudko, V. V., Rode, M., Basquin, C., Seraphin, B. and Conti, E. (2012). Architecture of the nuclease module of the yeast Ccr4-Not complex: the Not1-Caf1-Ccr4 interaction. Mol Cell 48, 207-18.

Berko, D., Herkon, O., Braunstein, I., Isakov, E., David, Y., Ziv, T., Navon, A. and Stanhill, A. (2014). Inherent asymmetry in the 26S proteasome is defined by the ubiquitin receptor RPN13. J Biol Chem 289, 5609-18.

Boeke, J. D., LaCroute, F. and Fink, G. R. (1984). A positive selection for mutants lacking orotidine-5'-phosphate decarboxylase activity in yeast: 5-fluoroorotic acid resistance. Mol Gen Genet 197, 345-6.

Budenholzer, L., Cheng, C. L., Li, Y. and Hochstrasser, M. (2017). Proteasome Structure and Assembly. J Mol Biol 429, 3500-3524.

Chen, J., Rappsilber, J., Chiang, Y. C., Russell, P., Mann, M. and Denis, C. L. (2001). Purification and characterization of the 1.0 MDa CCR4-NOT complex identifies two novel components of the complex. J Mol Biol 314, 683-94.

Chen, L. and Madura, K. (2002). Rad23 promotes the targeting of proteolytic substrates to the proteasome. Mol Cell Biol 22, 4902-13.

Collart, M. A. (2003). Global control of gene expression in yeast by the Ccr4-Not complex. Gene 313, 1-16.

Collart, M. A. and Panasenko, 0. 0. (2017). The Ccr4-Not Complex: Architecture and Structural Insights. Subcell Biochem 83, 349-379. 
Cooper, K. F., Scarnati, M. S., Krasley, E., Mallory, M. J., Jin, C., Law, M. J. and Strich, R. (2012). Oxidative-stress-induced nuclear to cytoplasmic relocalization is required for Not4-dependent cyclin C destruction. J Cell Sci 125, 1015-26.

Dikic, I. (2017). Proteasomal and Autophagic Degradation Systems. Annu Rev Biochem 86, 193-224.

Dohmen, R. J., Madura, K., Bartel, B. and Varshavsky, A. (1991). The N-end rule is mediated by the UBC2(RAD6) ubiquitin-conjugating enzyme. Proc Natl Acad Sci U S A 88, 7351-5.

Duttler, S., Pechmann, S. and Frydman, J. (2013). Principles of cotranslational ubiquitination and quality control at the ribosome. Mol Cell 50, 379-93.

Ellison, M. J. and Hochstrasser, M. (1991). Epitope-tagged ubiquitin. A new probe for analyzing ubiquitin function. J Biol Chem 266, 21150-7.

Fu, X., Sokolova, V., Webb, K. J., Old, W. and Park, S. (2018). Ubiquitindependent switch during assembly of the proteasomal ATPases mediated by Not4 ubiquitin ligase. Proc Natl Acad Sci U S A 115, 13246-13251.

Ghislain, M., Dohmen, R. J., Levy, F. and Varshavsky, A. (1996). Cdc48p interacts with Ufd3p, a WD repeat protein required for ubiquitin-mediated proteolysis in Saccharomyces cerevisiae. Embo j 15, 4884-99.

Gietz, R. D. and Sugino, A. (1988). New yeast-Escherichia coli shuttle vectors constructed with in vitro mutagenized yeast genes lacking six-base pair restriction sites. Gene 74, 527-34.

Godderz, D., Schafer, E., Palanimurugan, R. and Dohmen, R. J. (2011). The Nterminal unstructured domain of yeast ODC functions as a transplantable and replaceable ubiquitin-independent degron. J Mol Biol 407, 354-67.

Gulshan, K., Thommandru, B. and Moye-Rowley, W. S. (2012). Proteolytic degradation of the Yap1 transcription factor is regulated by subcellular localization and the E3 ubiquitin ligase Not4. J Biol Chem 287, 26796-805.

Halter, D., Collart, M. A. and Panasenko, O. 0. (2014). The Not4 E3 ligase and CCR4 deadenylase play distinct roles in protein quality control. PLoS One 9, e86218.

Hofmann, K. and Falquet, L. (2001). A ubiquitin-interacting motif conserved in components of the proteasomal and lysosomal protein degradation systems. Trends Biochem Sci 26, 347-50.

Husnjak, K., Elsasser, S., Zhang, N., Chen, X., Randles, L., Shi, Y., Hofmann, K., Walters, K. J., Finley, D. and Dikic, I. (2008). Proteasome subunit Rpn13 is a novel ubiquitin receptor. Nature 453, 481-8. 
Hwang, C. S., Shemorry, A., Auerbach, D. and Varshavsky, A. (2010). The Nend rule pathway is mediated by a complex of the RING-type Ubr1 and HECTtype Ufd4 ubiquitin ligases. Nat Cell Biol 12, 1177-85.

Inada, T. and Makino, S. (2014). Novel roles of the multi-functional CCR4-NOT complex in post-transcriptional regulation. Front Genet 5, 135.

Johnson, E. S., Ma, P. C., Ota, I. M. and Varshavsky, A. (1995). A proteolytic pathway that recognizes ubiquitin as a degradation signal. $J$ Biol Chem 270, 17442-56.

Kang, Y., Vossler, R. A., Diaz-Martinez, L. A., Winter, N. S., Clarke, D. J. and Walters, K. J. (2006). UBL/UBA ubiquitin receptor proteins bind a common tetraubiquitin chain. J Mol Biol 356, 1027-35.

Keskeny, C., Raisch, T., Sgromo, A., Igreja, C., Bhandari, D., Weichenrieder, O. and Izaurralde, E. (2019). A conserved CAF40-binding motif in metazoan NOT4 mediates association with the CCR4-NOT complex. Genes Dev 33, 236-252.

Kurian, L., Palanimurugan, R., Godderz, D. and Dohmen, R. J. (2011). Polyamine sensing by nascent ornithine decarboxylase antizyme stimulates decoding of its mRNA. Nature 477, 490-4.

Laribee, R. N., Shibata, Y., Mersman, D. P., Collins, S. R., Kemmeren, P., Roguev, A., Weissman, J. S., Briggs, S. D., Krogan, N. J. and Strahl, B. D. (2007). CCR4/NOT complex associates with the proteasome and regulates histone methylation. Proc Natl Acad Sci U S A 104, 5836-41.

London, M. K., Keck, B. I., Ramos, P. C. and Dohmen, R. J. (2004). Regulatory mechanisms controlling biogenesis of ubiquitin and the proteasome. FEBS Lett 567, 259-64.

Madura, K., Dohmen, R. J. and Varshavsky, A. (1993). N-recognin/Ubc2 interactions in the N-end rule pathway. J Biol Chem 268, 12046-54.

Marques, A. J., Palanimurugan, R., Matias, A. C., Ramos, P. C. and Dohmen, R. J. (2009). Catalytic mechanism and assembly of the proteasome. Chem Rev 109, 1509-36.

Mayor, T., Lipford, J. R., Graumann, J., Smith, G. T. and Deshaies, R. J. (2005). Analysis of polyubiquitin conjugates reveals that the Rpn10 substrate receptor contributes to the turnover of multiple proteasome targets. Mol Cell Proteomics 4, 741-51.

Mersman, D. P., Du, H. N., Fingerman, I. M., South, P. F. and Briggs, S. D. (2009). Polyubiquitination of the demethylase Jhd2 controls histone methylation and gene expression. Genes Dev 23, 951-62. 
Morita, M., Oike, Y., Nagashima, T., Kadomatsu, T., Tabata, M., Suzuki, T., Nakamura, T., Yoshida, N., Okada, M. and Yamamoto, T. (2011). Obesity resistance and increased hepatic expression of catabolism-related mRNAs in Cnot3+/- mice. Embo j 30, 4678-91.

Nakayama, K. I. and Nakayama, K. (2006). Ubiquitin ligases: cell-cycle control and cancer. Nat Rev Cancer 6, 369-81.

Page, A. M. and Hieter, P. (1999). The anaphase-promoting complex: new subunits and regulators. Annu Rev Biochem 68, 583-609.

Palanimurugan, R., Scheel, H., Hofmann, K. and Dohmen, R. J. (2004). Polyamines regulate their synthesis by inducing expression and blocking degradation of ODC antizyme. Embo $j$ 23, 4857-67.

Panasenko, 0., Landrieux, E., Feuermann, M., Finka, A., Paquet, N. and Collart, M. A. (2006). The yeast Ccr4-Not complex controls ubiquitination of the nascent-associated polypeptide (NAC-EGD) complex. J Biol Chem 281, 31389-98.

Panasenko, 0. 0. and Collart, M. A. (2012). Presence of Not5 and ubiquitinated Rps7A in polysome fractions depends upon the Not4 E3 ligase. Mol Microbiol 83, 640-53.

Paraskevopoulos, K., Kriegenburg, F., Tatham, M. H., Rosner, H. I., Medina, B., Larsen, I. B., Brandstrup, R., Hardwick, K. G., Hay, R. T., Kragelund, B. B. et al. (2014). Dss1 is a 26S proteasome ubiquitin receptor. Mol Cell 56, 453-61.

Peters, J. M. (1998). SCF and APC: the Yin and Yang of cell cycle regulated proteolysis. Curr Opin Cell Biol 10, 759-68.

Petit, A. P., Wohlbold, L., Bawankar, P., Huntzinger, E., Schmidt, S., Izaurralde, E. and Weichenrieder, 0. (2012). The structural basis for the interaction between the CAF1 nuclease and the NOT1 scaffold of the human CCR4-NOT deadenylase complex. Nucleic Acids Res 40, 11058-72.

Preissler, S., Reuther, J., Koch, M., Scior, A., Bruderek, M., Frickey, T. and Deuerling, E. (2015). Not4-dependent translational repression is important for cellular protein homeostasis in yeast. Embo j 34, 1905-24.

Ramos, P. C., Hockendorff, J., Johnson, E. S., Varshavsky, A. and Dohmen, R. J. (1998). Ump1p is required for proper maturation of the $20 \mathrm{~S}$ proteasome and becomes its substrate upon completion of the assembly. Cell 92, 489-99.

Reinstein, E. and Ciechanover, A. (2006). Narrative review: protein degradation and human diseases: the ubiquitin connection. Ann Intern Med 145, 676-84. 
Richly, H., Rape, M., Braun, S., Rumpf, S., Hoege, C. and Jentsch, S. (2005). A series of ubiquitin binding factors connects CDC48/p97 to substrate multiubiquitylation and proteasomal targeting. Cell 120, 73-84.

Rose, A. and Mayor, T. (2018). Exploring the Rampant Expansion of Ubiquitin Proteomics. Methods Mol Biol 1844, 345-362.

Rosenzweig, R., Bronner, V., Zhang, D., Fushman, D. and Glickman, M. H. (2012). Rpn 1 and Rpn2 coordinate ubiquitin processing factors at proteasome. J Biol Chem 287, 14659-71.

Rousseau, A. and Bertolotti, A. (2018). Regulation of proteasome assembly and activity in health and disease. Nat Rev Mol Cell Biol 19, 697-712.

Rubin, D. M., van Nocker, S., Glickman, M., Coux, O., Wefes, I., Sadis, S., Fu, H., Goldberg, A., Vierstra, R. and Finley, D. (1997). ATPase and ubiquitin-binding proteins of the yeast proteasome. Mol Biol Rep 24, 17-26.

Saeki, Y. (2017). Ubiquitin recognition by the proteasome. J Biochem 161, 113124.

Shi, Y., Chen, X., Elsasser, S., Stocks, B. B., Tian, G., Lee, B. H., Shi, Y., Zhang, N., de Poot, S. A., Tuebing, F. et al. (2016). Rpn1 provides adjacent receptor sites for substrate binding and deubiquitination by the proteasome. Science $\mathbf{3 5 1}$.

Sikorski, R. S. and Hieter, P. (1989). A system of shuttle vectors and yeast host strains designed for efficient manipulation of DNA in Saccharomyces cerevisiae. Genetics 122, 19-27.

Simonetti, F., Candelli, T., Leon, S., Libri, D. and Rougemaille, M. (2017). Ubiquitination-dependent control of sexual differentiation in fission yeast. Elife $\mathbf{6}$

Temme, C., Zhang, L., Kremmer, E., Ihling, C., Chartier, A., Sinz, A., Simonelig, M. and Wahle, E. (2010). Subunits of the Drosophila CCR4-NOT complex and their roles in mRNA deadenylation. Rna 16, 1356-70.

Varshavsky, A. (2011). The N-end rule pathway and regulation by proteolysis. Protein Sci 20, 1298-345.

Varshavsky, A. (2017). The Ubiquitin System, Autophagy, and Regulated Protein Degradation. Annu Rev Biochem 86, 123-128.

Villanyi, Z., Ribaud, V., Kassem, S., Panasenko, O. O., Pahi, Z., Gupta, I., Steinmetz, L., Boros, I. and Collart, M. A. (2014). The Not5 subunit of the Ccr4Not complex connects transcription and translation. PLoS Genet 10, e1004569.

Vinciguerra, M., Musaro, A. and Rosenthal, N. (2010). Regulation of muscle atrophy in aging and disease. Adv Exp Med Biol 694, 211-33. 
Vodermaier, H. C. (2004). APC/C and SCF: controlling each other and the cell cycle. Curr Biol 14, R787-96.

Winkler, G. S. and Balacco, D. L. (2013). Heterogeneity and complexity within the nuclease module of the Ccr4-Not complex. Front Genet 4, 296.

Xie, Y. and Varshavsky, A. (2001). RPN4 is a ligand, substrate, and transcriptional regulator of the $26 \mathrm{~S}$ proteasome: a negative feedback circuit. Proc Natl Acad Sci U S A 98, 3056-61. 


\section{Supplemental Information}

Table 1A: Strains

\begin{tabular}{|c|c|c|}
\hline Yeast strain & Genotype & Source \\
\hline BY4741-WT & $\begin{array}{l}\text { MATa his3- } \Delta 1 \text { leu2 } \Delta 0 \text { met15- } \Delta 0 \text { ura3- } \\
\Delta 0\end{array}$ & Euroscarf \\
\hline $\operatorname{ccr} 4 \Delta$ & $\begin{array}{l}\text { MATa his3- } \Delta 1 \text { leu } 2 \Delta 0 \text { met15- } \Delta 0 \text { ura3- } \\
\Delta 0 \text { ccr4::KanMX4 }\end{array}$ & Euroscarf \\
\hline ump1 $1 \Delta$ & $\begin{array}{l}\text { MATa his3- } \Delta 1 \text { leu2 } \Delta 0 \text { met15- } \triangle 0 \text { ura3- } \\
\Delta 0 \text { ump1::KanMX4 }\end{array}$ & Euroscarf \\
\hline not3 $\Delta$ & $\begin{array}{l}\text { MATa his3- } \Delta 1 \text { leu } 2 \Delta 0 \text { met15- } \Delta 0 \text { ura3- } \\
\Delta 0 \text { not3::KanMX4 }\end{array}$ & Euroscarf \\
\hline not $4 \Delta$ & $\begin{array}{l}\text { MATa his3- } \Delta 1 \text { leu } 2 \Delta 0 \text { met15- } \Delta 0 \text { ura3- } \\
\Delta 0 \text { not4::KanMX4 }\end{array}$ & Euroscarf \\
\hline not5 & $\begin{array}{l}\text { MATa his3- } \Delta 1 \text { leu2 } \Delta 0 \text { met15- } \Delta 0 \text { ura3- } \\
\Delta 0 \text { not5::KanMX4 }\end{array}$ & Euroscarf \\
\hline caf30s & $\begin{array}{l}\text { MATa his3- } \Delta 1 \text { leu2 } \Delta 0 \text { met15- } \Delta 0 \text { ura3- } \\
\Delta 0 \text { caf30::KanMX4 }\end{array}$ & Euroscarf \\
\hline caf140 & $\begin{array}{l}\text { MATa his3- } \Delta 1 \text { leu2 } \Delta 0 \text { met15- } \Delta 0 \text { ura3- } \\
\Delta 0 \text { caf140::KanMX4 }\end{array}$ & Euroscarf \\
\hline not1-ts & $\begin{array}{l}\text { MATa his3- } \triangle 1 \text { leu } 2 \Delta 0 \text { met15- } \Delta 0 \text { ura3- } \\
\Delta 0 \text { not1-ts::KanMX4 }\end{array}$ & Euroscarf \\
\hline not2-ts & $\begin{array}{l}\text { MATa his3- } \triangle 1 \text { leu } 2 \Delta 0 \text { met15- } \Delta 0 \text { ura3- } \\
\Delta 0 \text { not2-ts::KanMX4 }\end{array}$ & Euroscarf \\
\hline ufd $4 \Delta$ & $\begin{array}{l}\text { MATa his3- } \Delta 1 \text { leu2 } \triangle 0 \text { met15- } \triangle 0 \text { ura3- } \\
\Delta 0 \text { ufd4::KanMX4 }\end{array}$ & Euroscarf \\
\hline YAP16 & $\begin{array}{l}\text { MATa his3- } \triangle 1 \text { leu2 } \triangle 0 \text { met15- } \Delta 0 \text { ura3- } \\
\Delta 0 \text { trp1 } \triangle \text { KanMX4::P } P_{G A L 1}-P R E 2\end{array}$ & This study \\
\hline PYGA12 & $\begin{array}{l}\text { MATa his3- } \Delta 1 \text { leu2 } \Delta 0 \text { met15- } \Delta 0 \text { ura3- } \\
\Delta 0 \text { trp1 } \Delta\end{array}$ & This study \\
\hline PYGA14 & $\begin{array}{l}\text { MATa his3- } \Delta 1 \text { leu2 } \Delta 0 \text { met15- } \Delta 0 \text { ura3- } \\
\Delta 0 \text { trp1 } \Delta \text { ccr4::KanMX4 }\end{array}$ & This study \\
\hline
\end{tabular}


Table 1B: Primers

\begin{tabular}{|c|c|c|}
\hline Name & Nucleotide sequence & Description \\
\hline UC1 & ССTCTTCGCTATTACGCCAGC & $\begin{array}{l}\text { YCplac33-forward } \\
\text { primer }\end{array}$ \\
\hline UC2 & TTTATGCTTCCGGCTCGTATG & $\begin{array}{l}\text { YCplac33-reverse } \\
\text { primer }\end{array}$ \\
\hline GK268 & TGTTATCGCCCGTACTTGCGAAAAACGGGCCA & $\begin{array}{l}\text { CCR4 forward } \\
\text { sequencing primer }\end{array}$ \\
\hline GK286 & GAGCATGTTCGCGTTCCCATTAGCCAATTG & $\begin{array}{l}\text { CCR4 internal reverse } \\
\text { primer } 1\end{array}$ \\
\hline AP348 & CATTGAATTCCAACGATGAGCGC & $\mathrm{P}_{\mathrm{CCR} 4}$ forward primer \\
\hline AP349 & ATTGAAGCTTCCAGATCGGATTG & $\begin{array}{l}\text { CCR4 internal reverse } \\
\text { primer } 2\end{array}$ \\
\hline AP350 & CTGGAAGCTTCAATTGCATCTGG & $\begin{array}{l}\text { CCR4 internal forward } \\
\text { primer }\end{array}$ \\
\hline AP351 & GGGGTACCСCTCTGAATGCGTATCGGCCAG & $\mathrm{T}_{\mathrm{CCR} 4}$ reverse primer \\
\hline GK424 & $\begin{array}{l}\text { TTACGAGCTCAAGACCCAGAGATGTTGTTGTC } \\
\text { CTAGTTAC }\end{array}$ & $\mathrm{P}_{\mathrm{TPI} 1}$ forward primer \\
\hline GK425 & $\begin{array}{l}\text { ACTGGAATTCTTTTAGTTTATGTATGTGTTT } \\
\text { TTTGTAGTTA }\end{array}$ & $\mathrm{P}_{\text {TPI1 }}$ reverse primer \\
\hline GK426 & $\begin{array}{l}\text { AGTGGAATTCATGAACGACCCTTCTTTACTAG } \\
\text { GCTACCCT }\end{array}$ & CCR4 forward primer \\
\hline GK427 & $\begin{array}{l}\text { GTAAGGTACCTTACTTGTCATCGTCGTCCTTG } \\
\text { TAGTCCTTATCGTCATCGTCTTTGTAATCTTT } \\
\text { GTCATCATCGTCCTTATAGTCTACTTTCTTAC } \\
\text { TGCCTGTGTTTGTCTTCATA }\end{array}$ & $\begin{array}{l}\text { CCR4-3XFLAG reverse } \\
\text { primer }\end{array}$ \\
\hline GK428 & TTTAGGAGTTTAGTGAACTTGCAACAT & $\mathrm{P}_{\text {TPI1 }}$ primer \\
\hline
\end{tabular}




\begin{tabular}{|c|c|c|}
\hline GK449 & CTTCAATAATGCAAGGTGAATTGTAAAGAAA & $\begin{array}{l}\text { PRE2 -100bp forward } \\
\text { primer }\end{array}$ \\
\hline GK450 & CGATGGTGCCAAACGTTGAAACTGGGAGGC & $\begin{array}{l}\text { PRE2 + } 100 \mathrm{bp} \text { reverse } \\
\text { primer }\end{array}$ \\
\hline GK451 & GCAAAACGAAGAATAGCACTCCTTCAATAA & $\begin{array}{l}\text { PRE2 -150bp forward } \\
\text { primer }\end{array}$ \\
\hline GK418 & $\begin{array}{l}\text { ATCGAAGCTTTAGCGGTAGTTTGCAGGGATAACG } \\
\text { TCAGTCG }\end{array}$ & CCR4 promoter \\
\hline GK419 & $\begin{array}{l}\text { TCTGGAAGCTTATGTTGGCTACACAACAGGCTCA } \\
\text { GCAAGCTCAG }\end{array}$ & $\begin{array}{l}\text { Ccr4 } 188 \text { amino acid } \\
\text { forward }\end{array}$ \\
\hline GK420 & $\begin{array}{l}\text { TCTGGAAGCTTATGGACGACCAATTATGGCACGC } \\
\text { GCTAGATTTGT }\end{array}$ & $\begin{array}{l}\text { Ccr4 } 332 \text { amino acid } \\
\text { forward }\end{array}$ \\
\hline GK421 & $\begin{array}{l}\text { TCTGGAAGCTTATGTTACCATGGGAGTTTGGGAA } \\
\text { CCTGTGTAACC }\end{array}$ & $\begin{array}{l}\text { Ccr4 } 418 \text { amino acid } \\
\text { forward }\end{array}$ \\
\hline GK422 & $\begin{array}{l}\text { ATCGAAGGATCCTTATGTGGTGACCATGTTATCA } \\
\text { AAAAAGTAGAAG }\end{array}$ & $\begin{array}{l}\text { Ccr4 } 417 \text { amino acid } \\
\text { Reverse }\end{array}$ \\
\hline GK423 & $\begin{array}{l}\text { ATCGAAGGATCCACCGCACACTTTCATCCCACTCC } \\
\text { СTCССTCC }\end{array}$ & CCR4 terminator \\
\hline
\end{tabular}


Table 1C: Plasmids

\begin{tabular}{|c|c|c|}
\hline $\begin{array}{l}\text { Plasmid } \\
\text { Name }\end{array}$ & Description & $\begin{array}{c}\text { Reference/ } \\
\text { Sources }\end{array}$ \\
\hline Ycplac33 & CEN/ARS, URA3, AmpR & $\begin{array}{c}\text { (Gietz and } \\
\text { Sugino, 1988) }\end{array}$ \\
\hline Ycplac22 & CEN/ARS, TRP, AmpR & $\begin{array}{c}\text { (Gietz and } \\
\text { Sugino, 1988) }\end{array}$ \\
\hline Ycplac111 & CEN/ARS, LEU, AmpR & $\begin{array}{c}\text { (Gietz and } \\
\text { Sugino, 1988) }\end{array}$ \\
\hline YEP105 & $\mathrm{P}_{C U P 1^{-}}$MYC-UB, $2 \mu, \mathrm{TRP}, \mathrm{AmpR}$ & $\begin{array}{c}\text { (Ellison and } \\
\text { Hochstrasser, } \\
\text { 1991) }\end{array}$ \\
\hline pMAF18 & $\mathrm{P}_{\text {CUP1- }}$ Ub-V ${ }_{76}-\mathrm{eK}-\mathrm{HA}-\mathrm{URA} 3, \mathrm{CEN} / \mathrm{ARS}, \mathrm{LEU}, \mathrm{AmpR}$ & R.J. Dohmen \\
\hline pBA2VV & $\mathrm{P}_{\text {CUP1- }}$ Ub-V ${ }_{76}-\mathrm{eK}-\mathrm{HA}-\mathrm{URA} 3, \mathrm{CEN} / \mathrm{ARS}, \mathrm{TRP}, \mathrm{AmpR}$ & R.J. Dohmen \\
\hline pMAF17 & $\mathrm{P}_{C U P 1}-\mathrm{Ub}-\mathrm{R}-\mathrm{eK}-\mathrm{HA}-\mathrm{URA} 3, \mathrm{CEN} / \mathrm{ARS}, \mathrm{LEU}, \mathrm{AmpR}$ & R.J. Dohmen \\
\hline pDG258 & PODC-ODC1-42-URA3-2xHA, CEN/ARS, LEU, AmpR & $\begin{array}{c}\text { (Godderz et al., } \\
\text { 2011) }\end{array}$ \\
\hline pMAF56 & $\mathrm{P}_{\text {CUP1-DHFRWT-2HA, CEN/ARS, LEU, AmpR }}$ & R.J. Dohmen \\
\hline pMAF56C & P $_{\text {CUP1-DHFRmutC-2HA, CEN/ARS, LEU, AmpR }}$ & R.J. Dohmen \\
\hline pAK14 & 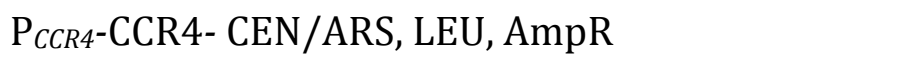 & Current study \\
\hline pAK20 & $\mathrm{P}_{T P I 1}-3 X-F L A G$-CCR4- CEN/ARS, URA3, AmpR & Current study \\
\hline pAK21 & 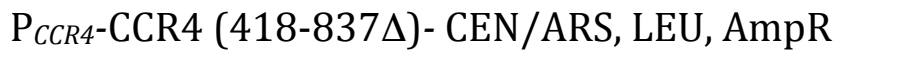 & Current study \\
\hline pGAP3 & $\mathrm{P}_{C C R 4-C C R 4}(1-187 \Delta)-\mathrm{CEN} / \mathrm{ARS}, \mathrm{LEU}, \mathrm{AmpR}$ & Current study \\
\hline pGAP4 & $\mathrm{P}_{C C R 4}-\mathrm{CCR} 4(1-331 \Delta)-\mathrm{CEN} / \mathrm{ARS}, \mathrm{LEU}, \mathrm{AmpR}$ & Current study \\
\hline pGAP5 & $\mathrm{P}_{C C R 4}-\mathrm{CCR} 4(1-417 \Delta)-\mathrm{CEN} / \mathrm{ARS}, \mathrm{LEU}, \mathrm{AmpR}$ & Current study \\
\hline
\end{tabular}




\section{Figure Legends}

\section{Figure 1: Illustration showing the various proteasome substrates}

Cartoon depicting the salient features of proteasome substrates used in this study that are degraded by ubiquitin-dependent protein degradation pathway namely the N-end rule (pMAF17), ubiquitin fusion degradation (UFD) (pMAF18), quality control pathway protein mouse Dhfrmutc (pMAF56C) and the ubiquitinindependent proteasome substrate ODS-Ura3 (pDG258).

Figure 2: Steady state level analysis of proteasome substrates in Ccr4-Not complex subunit mutants

(A). Western blot analysis of various substrate levels in WT, ccr4 $\Delta$ and ump1 $\Delta$ strains. WT and mutant transformants having pMAF17, pMAF18, pMAF56C and pDG258 were grown in the SD-leu and with $100 \mu \mathrm{M} \mathrm{CuSO}_{4}$ till the cultures reached mid-log phase at $25^{\circ} \mathrm{C}$. Cells were harvested and extract corresponding to $0.416 \mathrm{OD}_{600}$ was analyzed by western blotting. Substrate proteins were detected using anti-Ha (upper panels). Tpi1 and Pgk1 were used as a protein loading control (lower panels). Note that in ump1 $\Delta$ lanes the total protein loaded was less than WT and $c c r 4 \Delta$. Quantification of signals from blots shown in panel above. Error bars denote s.d.; $\mathrm{n} \geq 3$.

(B). The $c c r 4 \Delta$ (PYGA14) strain carrying pBA2VV along with CCR4 (pAK14) and CCR4-3XFLAG (pAK22) gene variants were grown in the SD-leu-trp with $100 \mu \mathrm{M}$ $\mathrm{CuSO}_{4}$ till the cultures reached mid-log phase at $25^{\circ} \mathrm{C}$. Cells were harvested and extract corresponding to $0.416 \mathrm{OD}_{600}$ was analyzed by western blotting. Substrate proteins were detected using anti-Ha (upper panels). Pgk1 was used as a protein loading control (lower panels). Quantification of signals from blots shown in panel B. Error bars denote s.d.; $\mathrm{n} \geq 3$.

Figure 3: Steady state level analysis of UFD substrate in various Ccr4-Not subunit mutants

(A). Western blot analysis of UFD substrate (Ub-V76-Ura3) levels in various Ccr4Not complex subunit deletion strains and temperature-sensitive mutants (ts). 
UFD substrate cassette was expressed from $P_{C U P 1}$ by adding $100 \mu \mathrm{M} \mathrm{CuSO}_{4}$ to growth medium. Stable deletion strains were grown and harvested at $25^{\circ} \mathrm{C}$ and $t s$ mutants (not1-ts and not2-ts, its isogenic WT strain) were initially grown at $25^{\circ} \mathrm{C}$ and later shifted to $37^{\circ} \mathrm{C}$ for $1 \mathrm{hr}$ before harvesting. Upper panel shows anti-Ha signals and the lower panel is showing loading control Tpi1 signals. Asterisk denotes degradation product of UFD substrate.

(B). Growth assay showing the accumulation of Ura3 based substrate proteins. WT, $c c r 4 \Delta, u m p 1 \Delta$, and $u f d 4 \Delta$ having empty plasmid and pMAF18 were grown to mid-log phase. Then cells were spotted ( $3 \mu \mathrm{l}$ from $10 \mathrm{OD}_{600} / \mathrm{ml}$ suspension) on selection plates as indicated. Plates were incubated at $25^{\circ} \mathrm{C}$ for 4 days and photographed.

\section{Figure 4: Cycloheximide chase assay for UFD substrate degradation}

(A). WT, ccr4 4 and ump1 $\Delta$ strains were transformed with pMAF18 expressing UFD cassette and the cells were grown in SD-leu with $100 \mu \mathrm{M} \mathrm{CuSO}_{4}$ till mid-log phase at $25^{\circ} \mathrm{C}$. In the next step cycloheximide chase was done as mentioned in methods section and the samples were analyzed by western blotting. Anti-Ha was used for detecting the UFD substrate (Ub-V $\mathrm{V}_{76}-\mathrm{Ura} 3$ ) (upper panels). Pgk1 served as a loading control (lower panels).

(B). Quantification of the signals shown in panel. Error bars denote s.d.; $\mathrm{n} \geq 3$.

Figure 5: CCR4 deletion accumulates ubiquitin modified UFD substrates and Ccr4 binds to cellular ubiquitin conjugates

(A). Western blot showing the higher molecular weight ubiquitin conjugated UFD substrate in WT, ccr $4 \Delta$ and ump $1 \Delta$. Cells were grown at $25^{\circ} \mathrm{C}$ and samples were prepared as mentioned in methods section and loaded on low percent (8 \%) SDS-PAGE gel to resolve the higher molecular weight forms. Anti-Ha was used for detecting UFD substrate protein (upper panel) and anti-Tpi1 was used 
for detecting the loading control (lower panel). Asterisk indicates nonspecific band.

(B). Western blot showing association of higher molecular weight cellular ubiquitin conjugates with Ccr4-3XFLAG protein in native co-immuno precipitation experiment. YAP16 strain carrying either vector alone and/or plasmids expressing MYC-UBI, CCR4-3XFLAG was grown and Ccr4-3XFLAG protein was immunoprecipitated as described in methods section. Input levels (left panel) and eluted IP materials (right panel) were analyzed by western blots using anti-Myc and anti-Flag antibodies. Anti-Tpi1 was used to detect the loading control.

Figure 6: Ccr4 does not bind to cellular ubiquitin conjugates under denaturation conditions

IP Experiments were done as in Figure 5B except the lysates were subjected to denaturation by addition of $2 \%$ SDS, $1 \% \beta$-mercaptoethanol and heating at $95^{\circ} \mathrm{C}$ for $5 \mathrm{~min}$. Ccr4-3XFLAG protein was immunoprecipitated as described in methods section. Input levels (left panel) and IP eluate (right panel) were analyzed by western blots using anti-Myc and anti-Flag antibodies. Tpi1 was used as loading control.

\section{Figure 7: Ccr4 binds to $19 \mathrm{~S}$ regulatory particle subunit complex}

Western blot showing the association of Rpt5 subunit with 3X-FLAG-Ccr4. CO-IP experiment was performed as described in Figure 5B and also refer methods section. Input levels (left panel) and IP eluate (right panel) were analyzed by western blots using anti-Rpt5 and anti-Flag antibodies. Tpi1 was used as loading control. Asterisk denotes degradation product of Rpt5.

\section{Figure 8: Effects of CCR4 truncations on UFD substrate degradation.}

(A) Cartoon illustrating different truncation of yeast Ccr4 protein. (B) Steady state levels of UFD substrate (Ub-V76-Ura3) levels in various CCR4 truncation mutants. (C) Densitometric analysis of Ub-V76-Ura3 protein levels. (D) Growth assay showing the accumulation of Ura3 based UFD substrate protein. $c c r 4 \Delta$ 
mutant strain carrying either empty plasmid vector or plasmid expressing either full length CCR4 or its different truncation variants were co-transformed with pBA2VV plasmid. Stabilization of UFD substrate was monitored based on the growth phenotype on Uracil lacking medium. cells were spotted on selection plates as indicated and photographed as described earlier in figure 3B. Anti-Ha and anti-Pgk1 antibodies were used for western blotting.

\section{Figure 9: Ccr4 is an ubiquitin-modified protein targeting factor}

Model showing the UFD pathway in eukaryotes. UFD substrate is ubiquitin modified by Uba1(E1), Ubc4/5(E2s), Ufd4(E3) then Cdc48 ${ }^{\text {Np14-Ufd1-Ufd2 }}$ optimizes the ubiquitin chain. At a post-ubiquitylation step Ccr4 binds on the one hand binds to the proteasome and on the other hand Ccr4 binds to the ubiquitin conjugates thereby promotes targeting of ubiquitin-modified proteins to the $26 \mathrm{~S}$ proteasome for degradation.

\section{Supplementary Figure 1: Cycloheximide chase assay for ODS-Ura3 and DhfrmutC substrate degradation}

(A). WT, ccr4 $\Delta$ and ump1 1 strains were transformed with pDG258 and pMAF56C. The cells were grown in SD-leu with $100 \mu \mathrm{M} \mathrm{CuSO}_{4}$ till mid-log phase at $25^{\circ} \mathrm{C}$. In the next step cycloheximide chase was done as mentioned in methods section and the samples were analyzed by western blotting. Anti-Ha was used for detecting ODS-Ura3 and DhfrmutC (upper panels). Tpi1 and Pgk1 served as loading controls (lower panels).

\section{Supplementary Figure 2: Steady state levels of Dhfr ${ }^{\mathrm{WT}}$ substrate.}

(A). Schematic represents construct details of pMAF56 plasmid producing stable Dhfr wild-type protein. (B). Western blot showing the steady state levels of DhfrWT protein in WT, ccr4 $\Delta$ and ump1s strains. Anti-Ha and anti-Pgk1 antibodies were used for immunoblot analysis. Data shown is the biological replicates of three independent samples. 
bioRxiv preprint doi: https://doi.org/10.1101/2020.03.30.015370; this version posted April 29, 2020. The copyright holder for this preprint (which was not certified by peer review) is the author/funder, who has granted bioRxiv a license to display the preprint in perpetuity. It is made available under aCC-BY-NC-ND 4.0 International license.

Fig 1

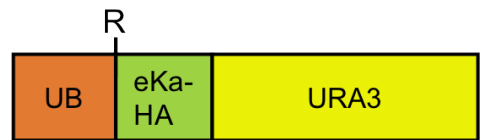

pMAF17

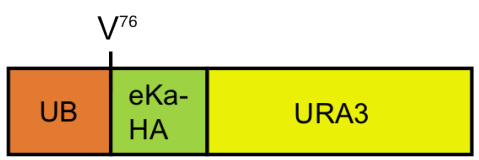

pMAF18/pBA2VV

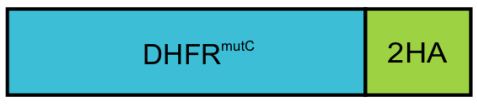

pMAF56C

\begin{tabular}{|l|l|l|}
\hline ODS & URA3 & 2HA \\
\hline
\end{tabular}

pDG258 
bioRxiv preprint doi: https://doi.org/10.1101/2020.03.30.015370; this version posted April 29, 2020. The copyright holder for this preprint

(which was not certified by peer review) is the author/funder, who has granted bioRxiv a license to display the preprint in perpetuity. It is made available under aCC-BY-NC-ND 4.0 International license.

Fig 2

A
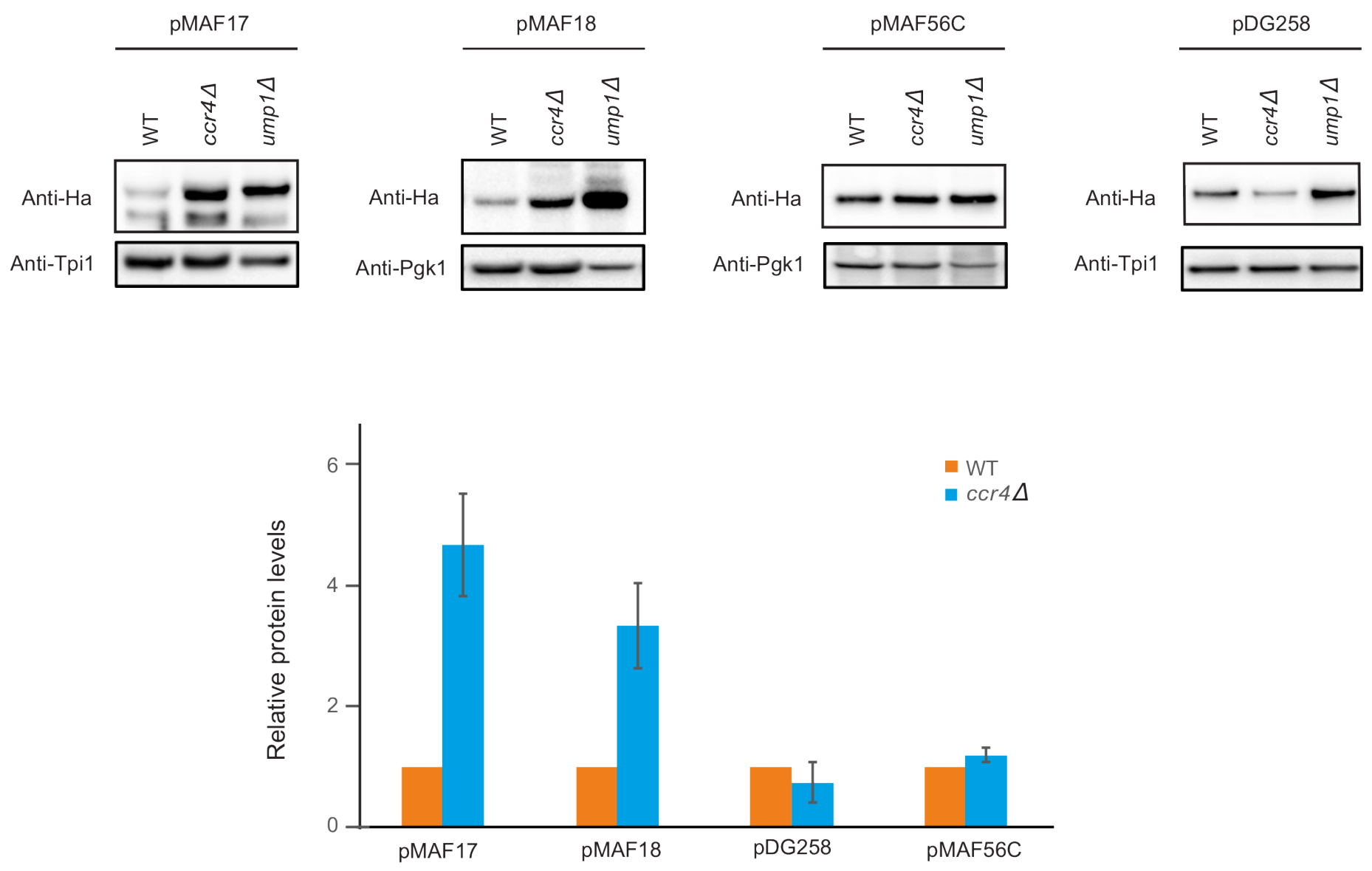

B
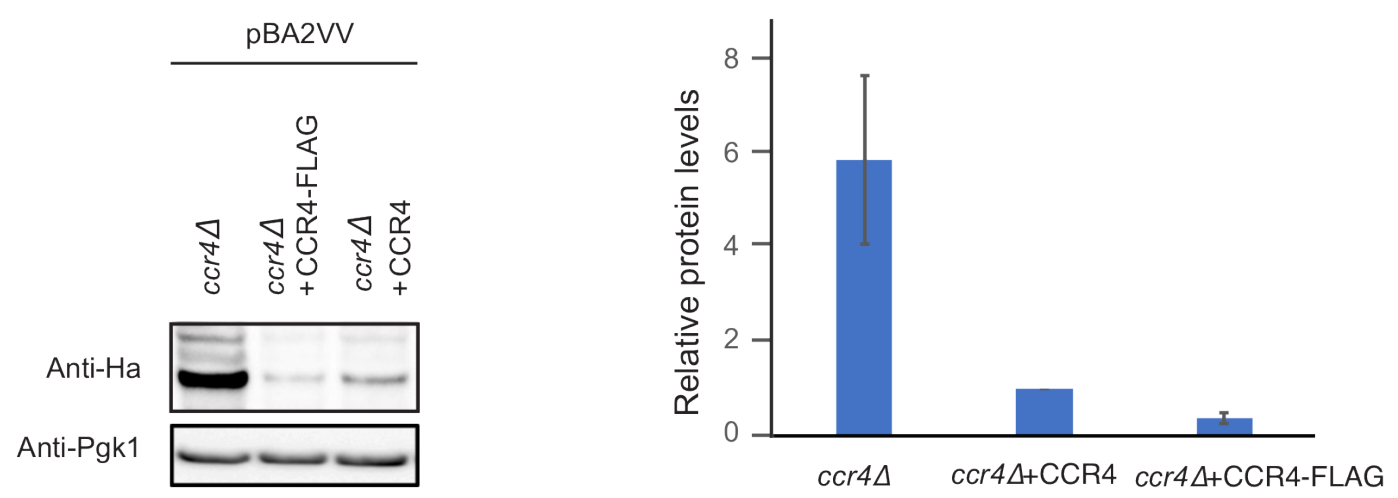
bioRxiv preprint doi: https://doi.org/10.1101/2020.03.30.015370; this version posted April 29, 2020. The copyright holder for this preprint (which was not certified by peer review) is the author/funder, who has granted bioRxiv a license to display the preprint in perpetuity. It is made available under aCC-BY-NC-ND 4.0 International license.

Fig 3

A

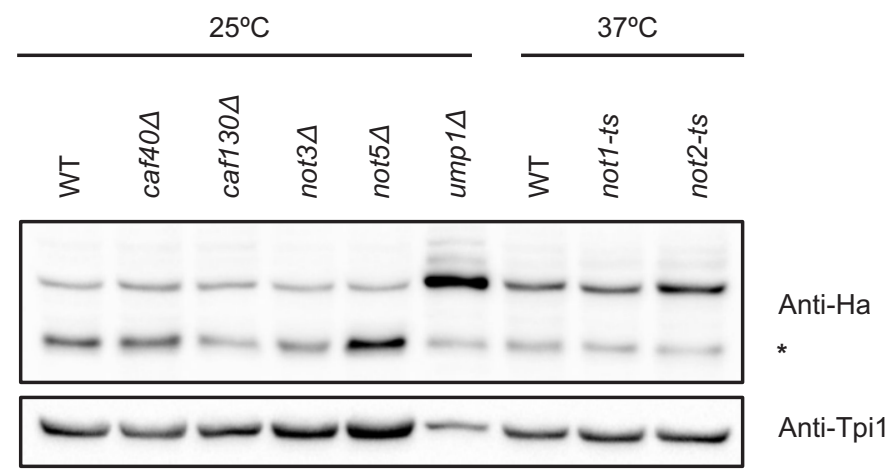

B

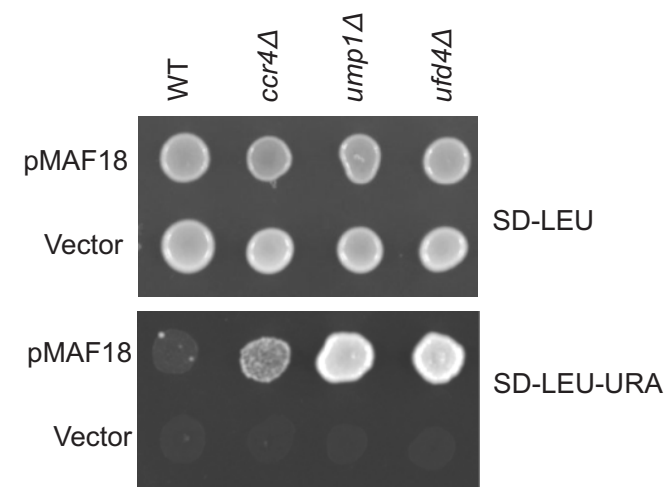


bioRxiv preprint doi: https://doi.org/10.1101/2020.03.30.015370; this version posted April 29, 2020. The copyright holder for this preprint

(which was not certified by peer review) is the author/funder, who has granted bioRxiv a license to display the preprint in perpetuity. It is made available under aCC-BY-NC-ND 4.0 International license.

\section{Fig 4}

A
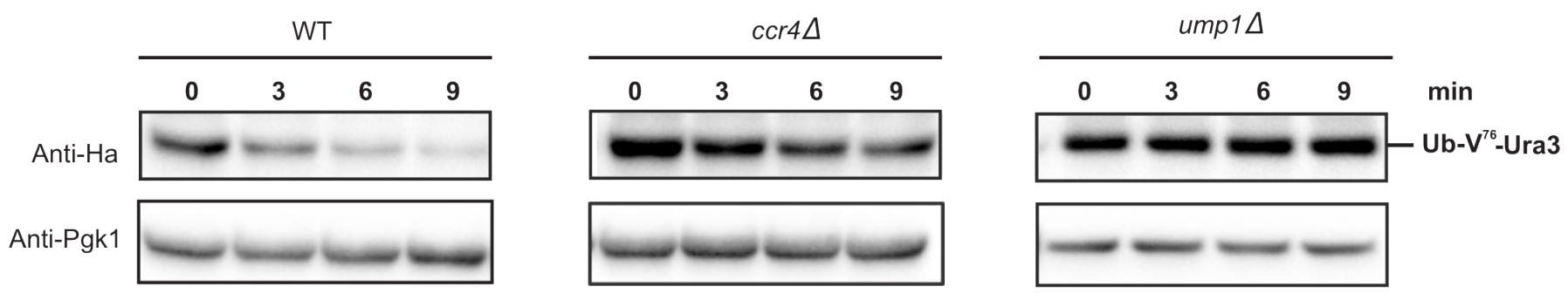

B

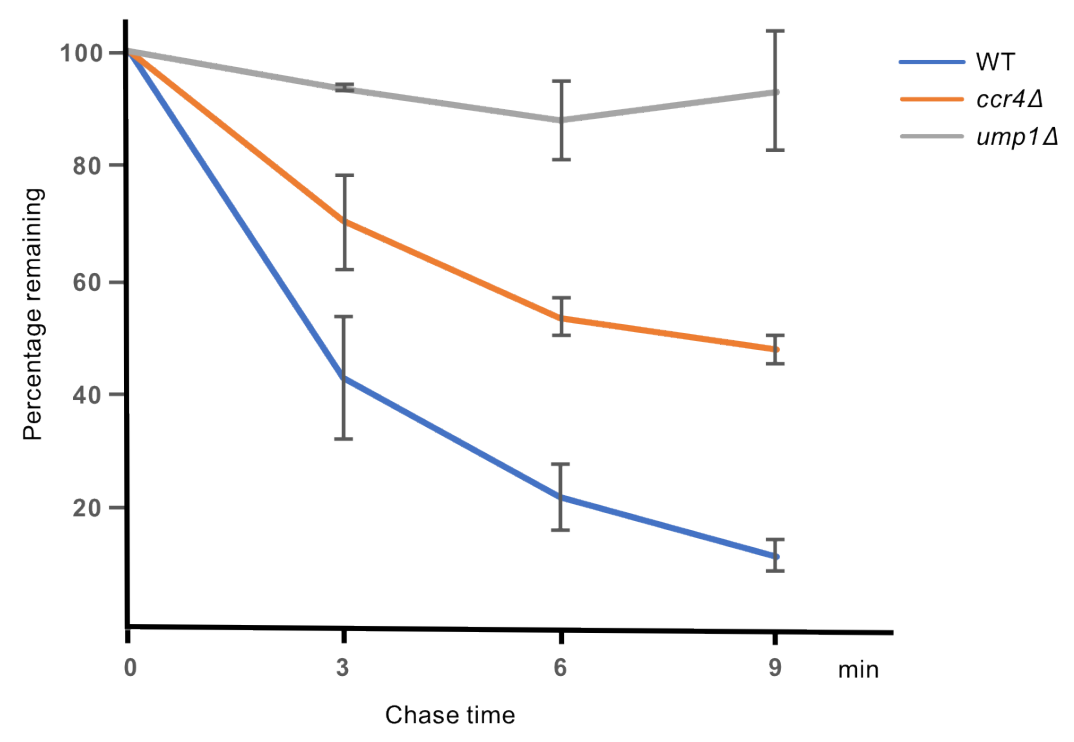


bioRxiv preprint doi: https://doi.org/10.1101/2020.03.30.015370; this version posted April 29, 2020. The copyright holder for this preprint

(which was not certified by peer review) is the author/funder, who has granted bioRxiv a license to display the preprint in perpetuity. It is made available under aCC-BY-NC-ND 4.0 International license.

Fig 5

A
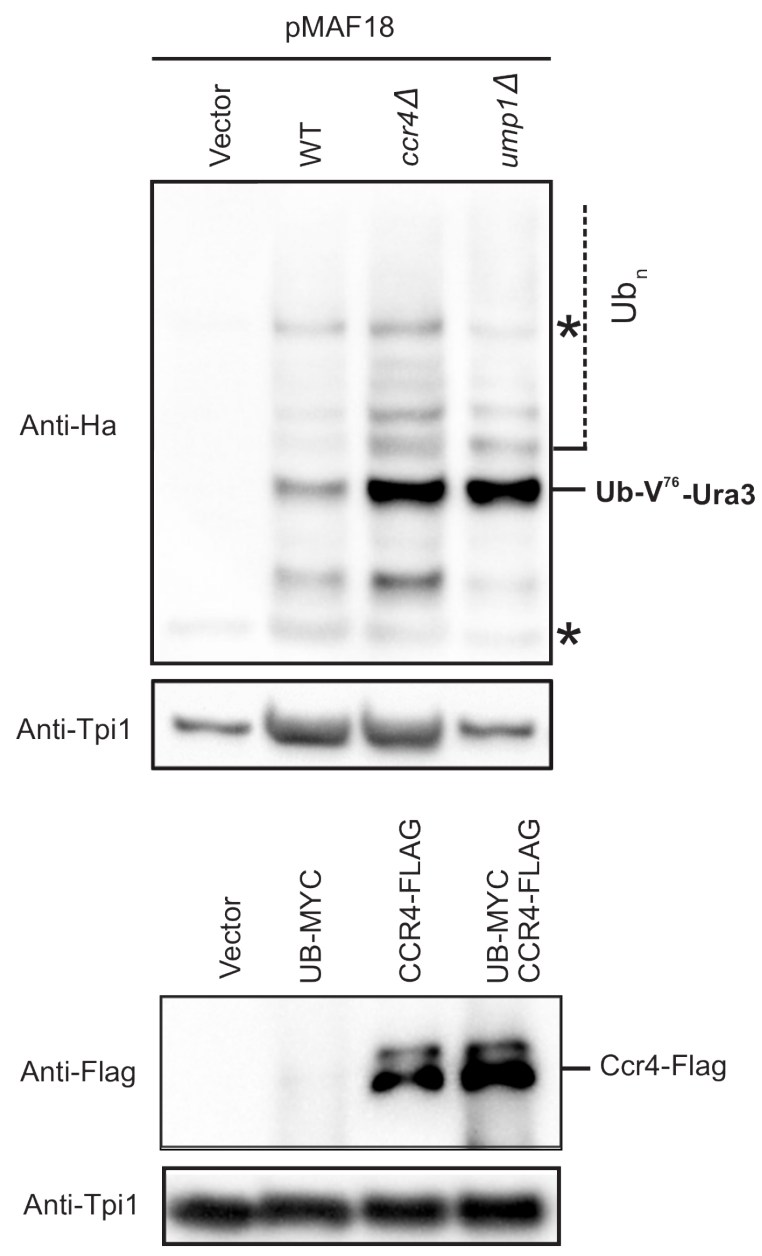

input

Anti-Myc
B

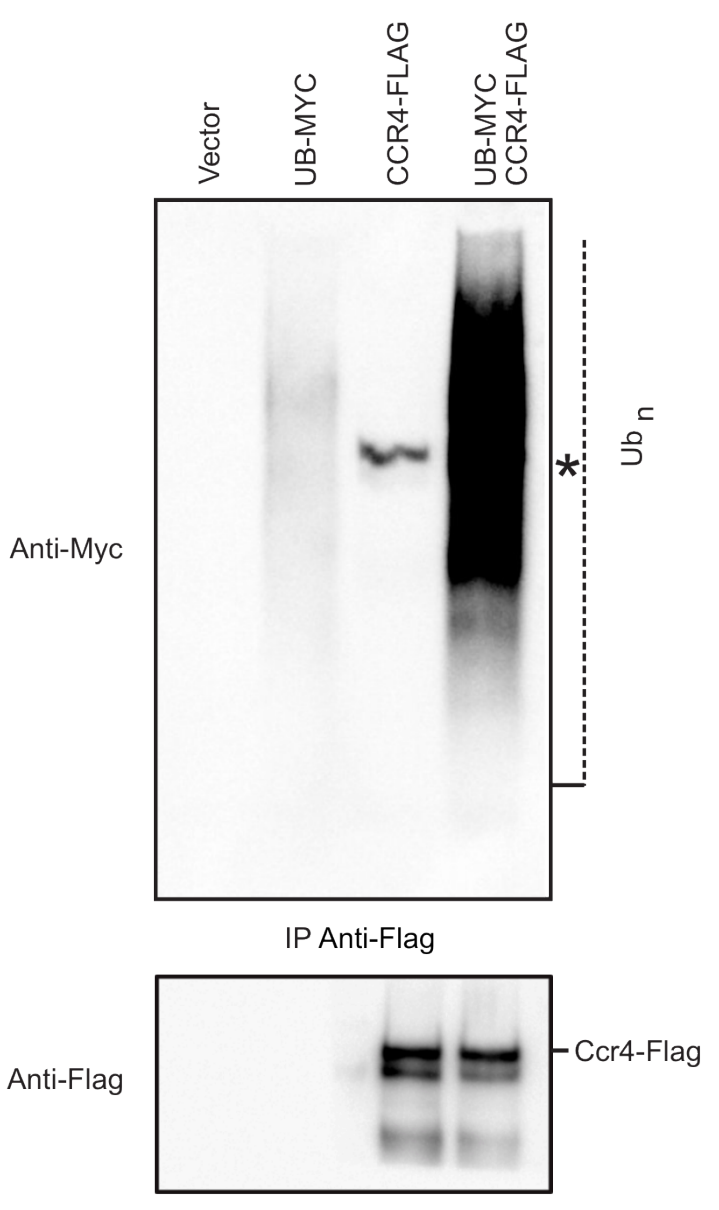


bioRxiv preprint doi: https://doi.org/10.1101/2020.03.30.015370; this version posted April 29, 2020. The copyright holder for this preprint (which was not certified by peer review) is the author/funder, who has granted bioRxiv a license to display the preprint in perpetuity. It is made available under aCC-BY-NC-ND 4.0 International license.

Fig 6
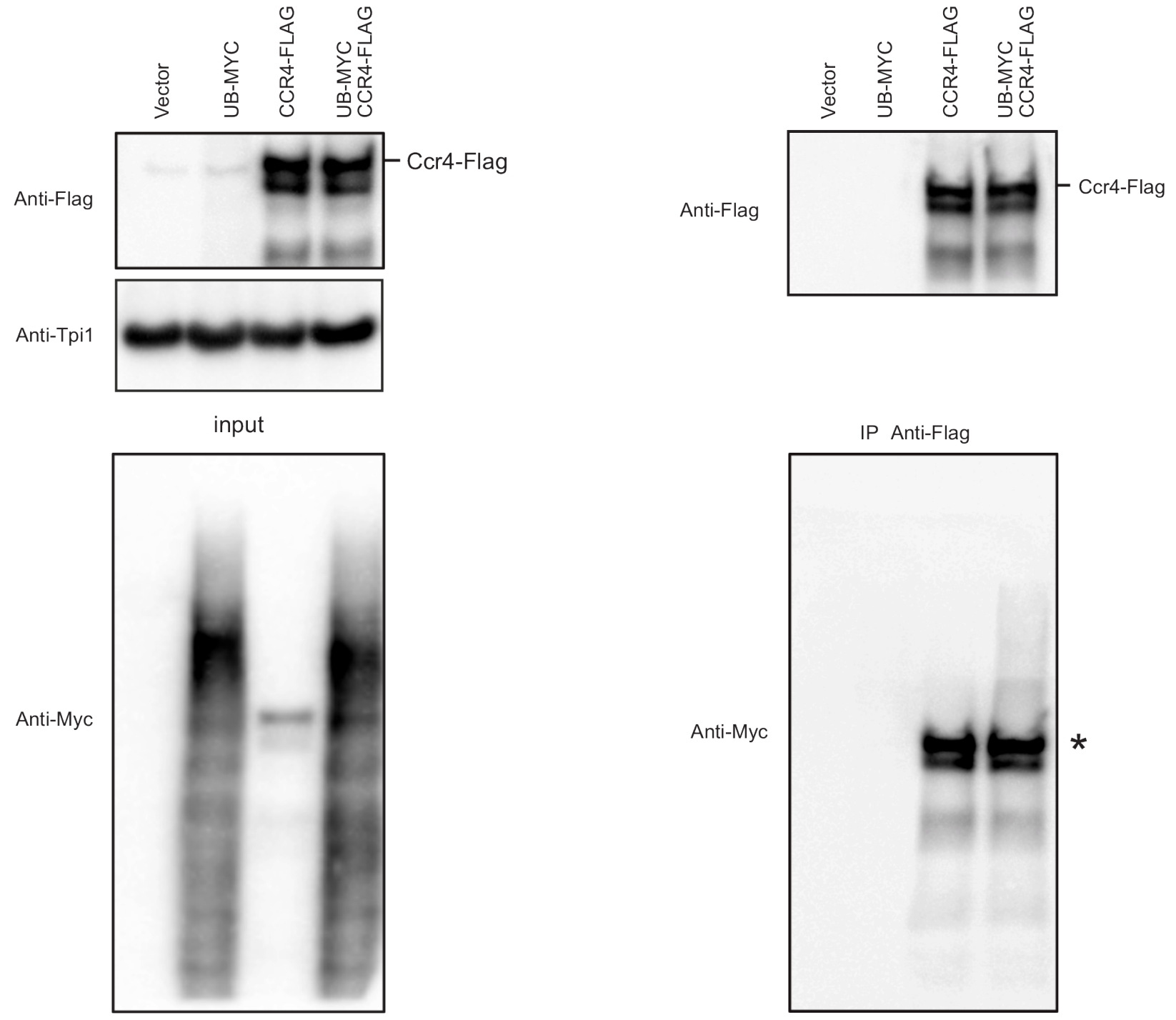
Fig 7
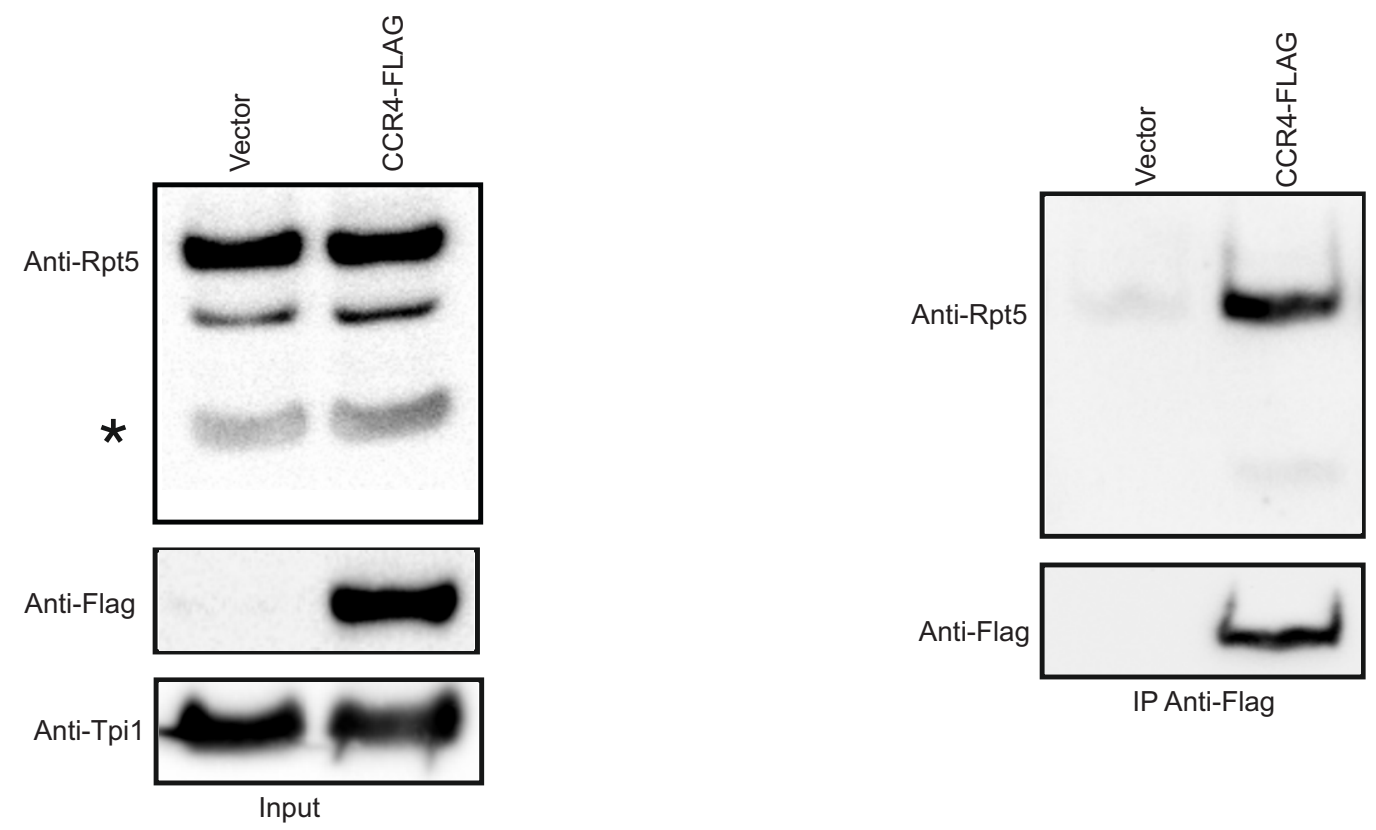
bioRxiv preprint doi: https://doi.org/10.1101/2020.03.30.015370; this version posted April 29, 2020. The copyright holder for this preprint (which was not certified by peer review) is the author/funder, who has granted bioRxiv a license to display the preprint in perpetuity. It is Fig 8

A

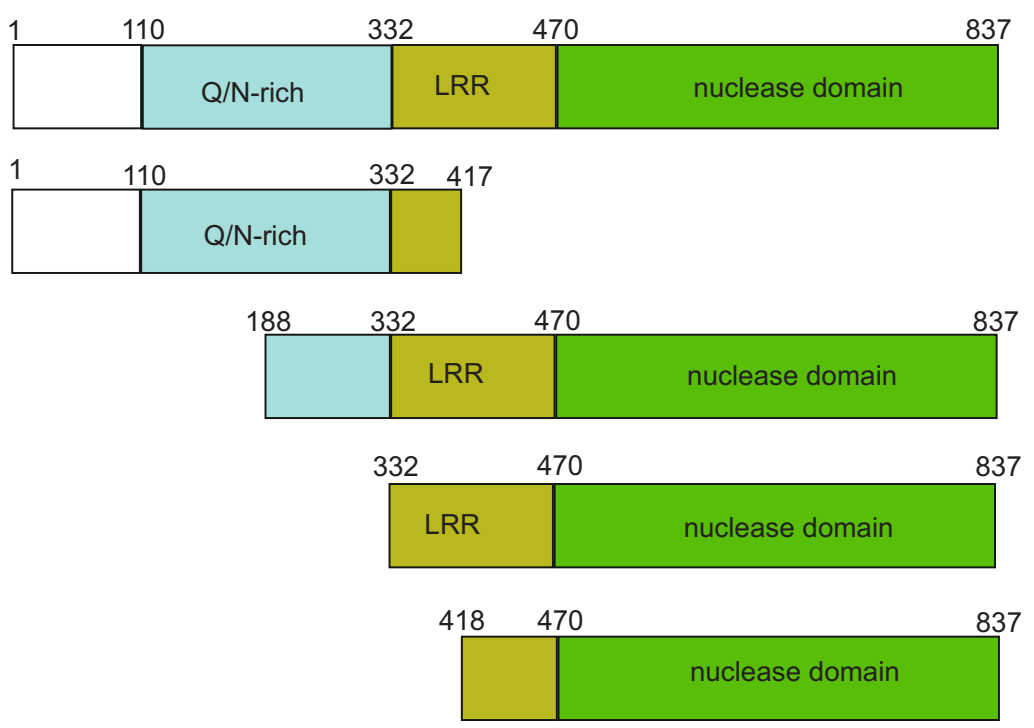

WT

B $\operatorname{ccr} 4 \Delta$

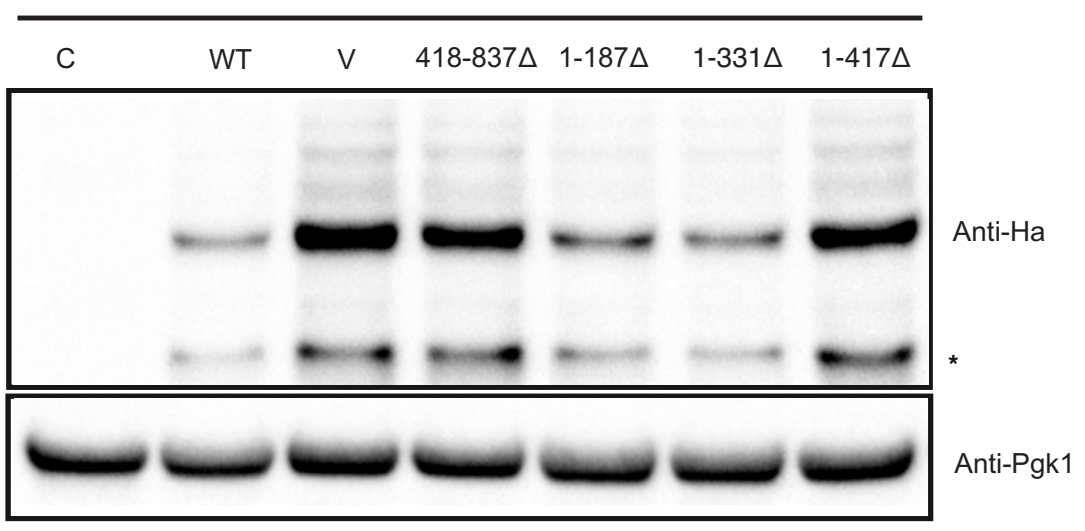

C

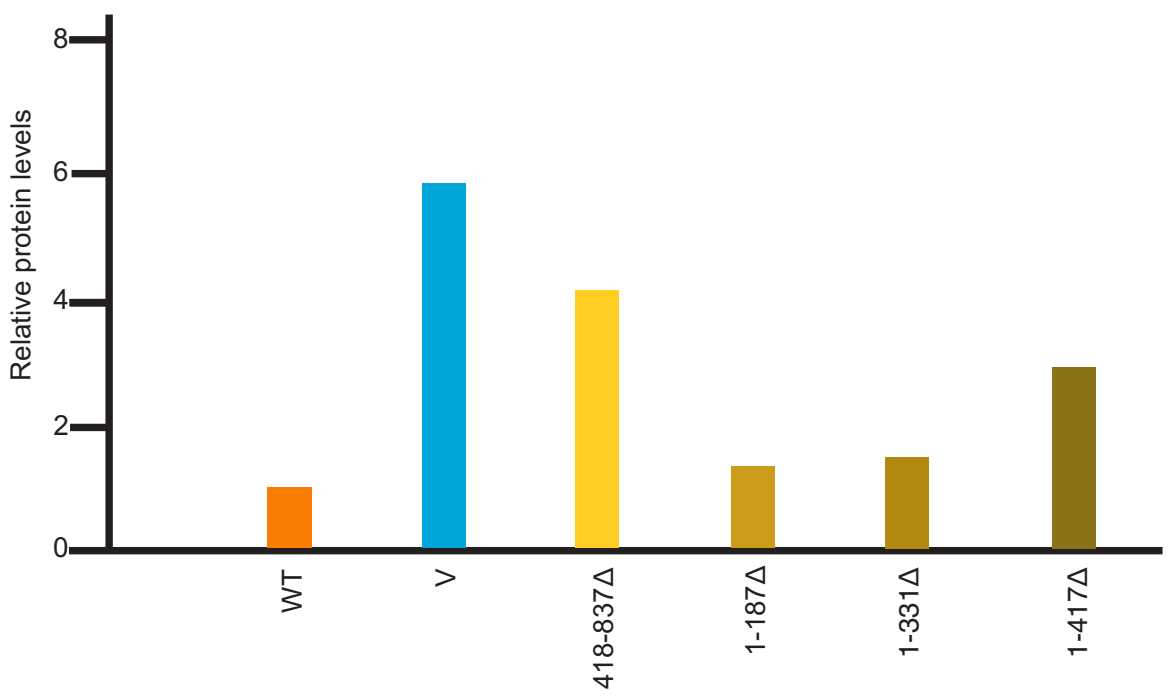

D

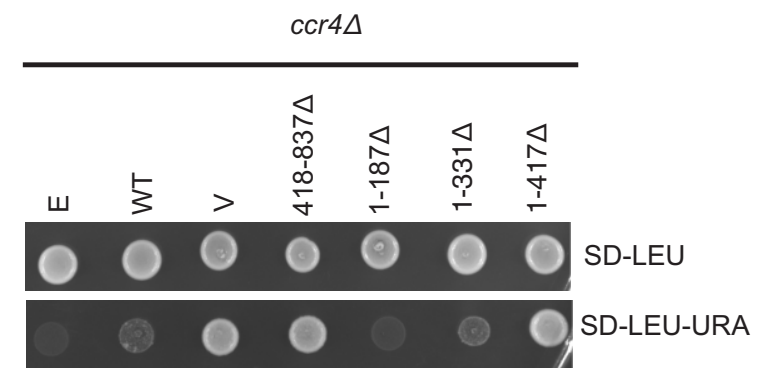


Fig 9

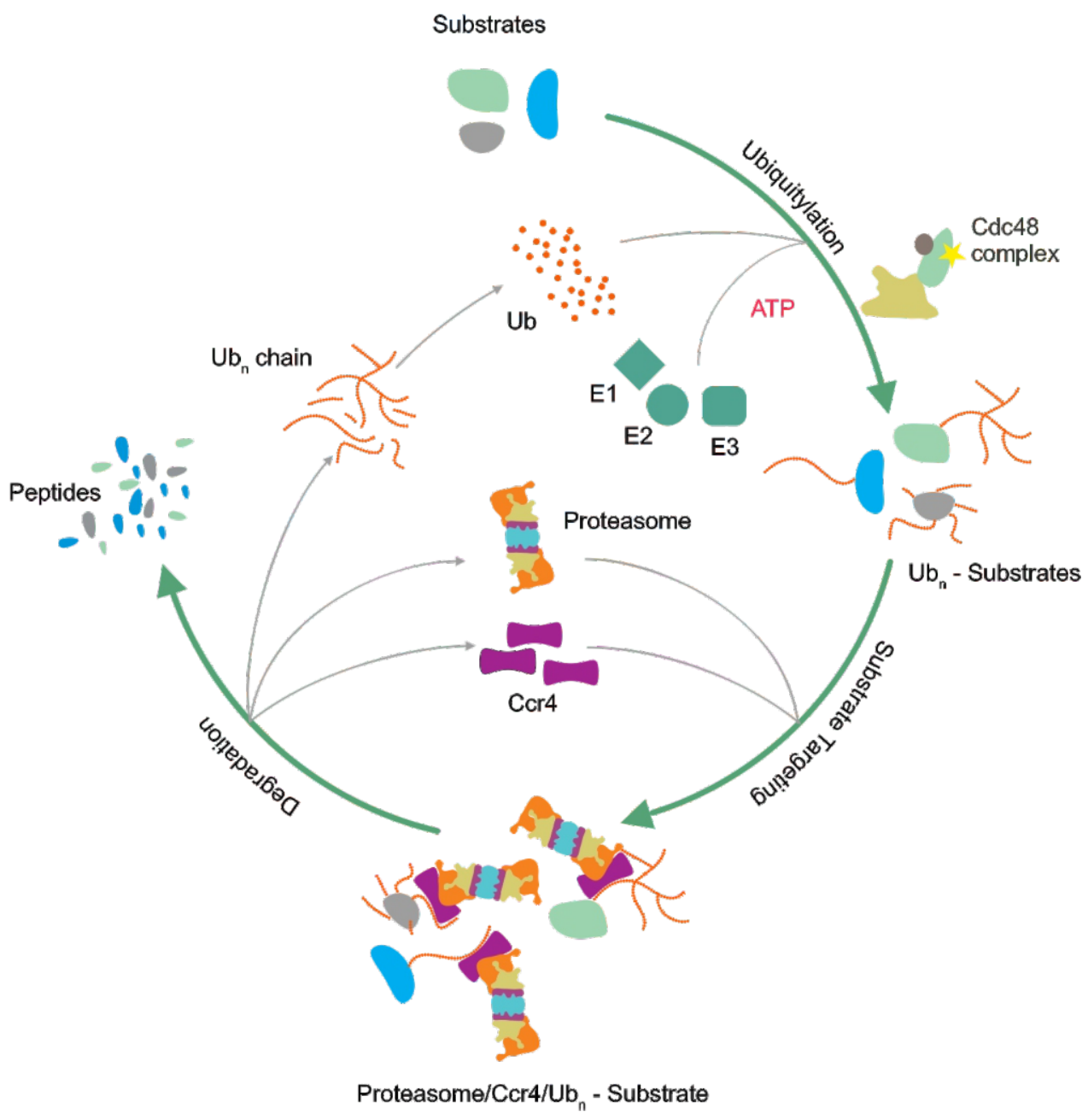


bioRxiv preprint doi: https://doi.org/10.1101/2020.03.30.015370; this version posted April 29, 2020. The copyright holder for this preprint (which was not certified by peer review) is the author/funder, who has granted bioRxiv a license to display the preprint in perpetuity. It is made available under aCC-BY-NC-ND 4.0 International license.

\section{Sup Fig 1}
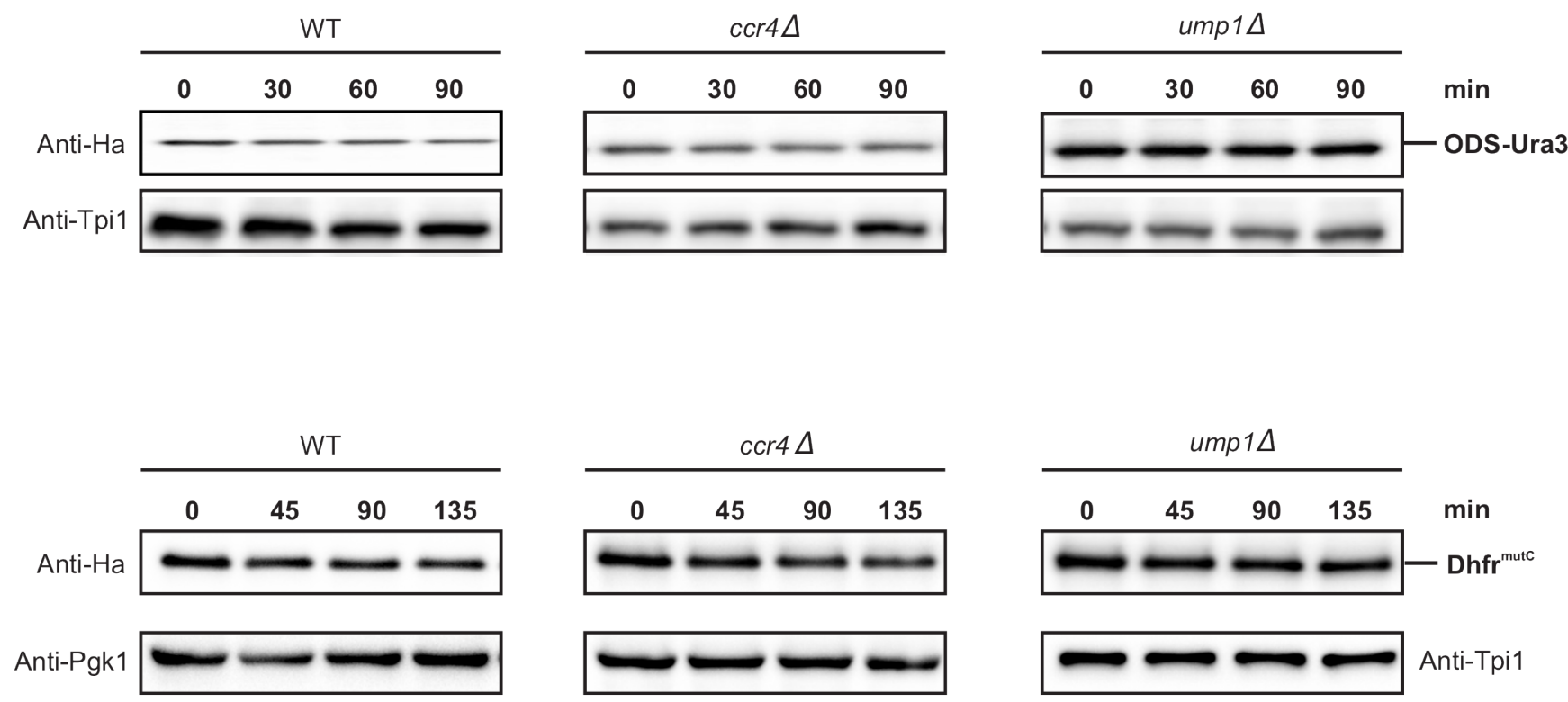


\section{Sup Fig 2}

A

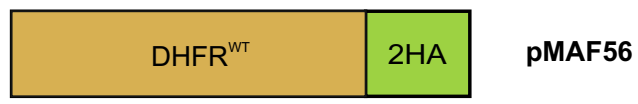

B

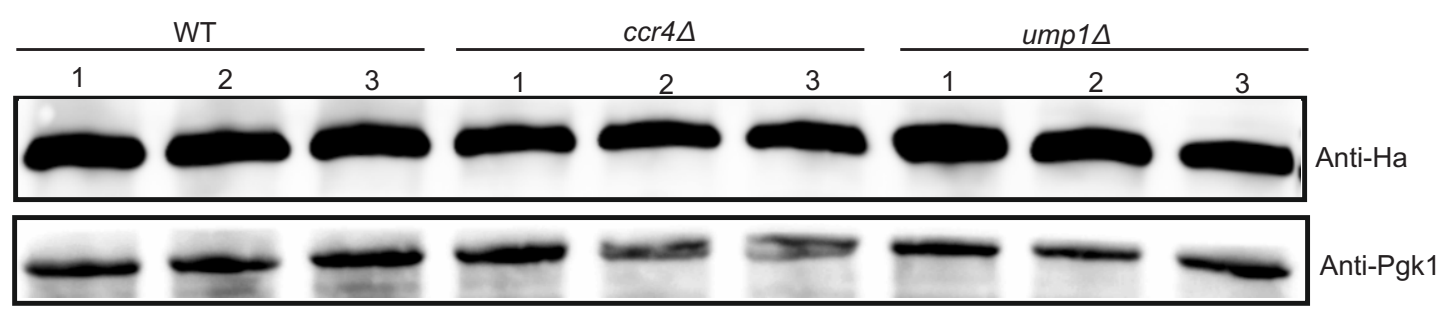

